Atmos. Chem. Phys., 17, 13071-13087, 2017

https://doi.org/10.5194/acp-17-13071-2017

(C) Author(s) 2017. This work is distributed under

the Creative Commons Attribution 3.0 License.

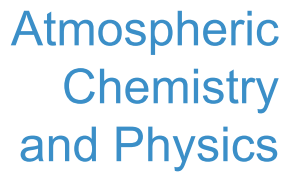

(c) (P)

\title{
Marine cloud brightening - as effective without clouds
}

\author{
Lars Ahlm ${ }^{1,2,3}$, Andy Jones ${ }^{4}$, Camilla W. Stjern ${ }^{3,5}$, Helene Muri ${ }^{3}$, Ben Kravitz ${ }^{6}$, and Jón Egill Kristjánsson ${ }^{3, \dagger}$ \\ ${ }^{1}$ Department of Meteorology, Stockholm University, Stockholm, Sweden \\ ${ }^{2}$ Bolin Centre for Climate Research, Stockholm University, Stockholm, Sweden \\ ${ }^{3}$ Department of Geosciences, University of Oslo, Oslo, Norway \\ ${ }^{4}$ Met Office Hadley Centre, Exeter, UK \\ ${ }^{5}$ Center for International Climate and Environmental Research - Oslo (CICERO), Oslo, Norway \\ ${ }^{6}$ Atmospheric Sciences and Global Change Division, Pacific Northwest National Laboratory, Richland, WA, USA \\ $\dagger$ deceased
}

Correspondence to: Lars Ahlm (lars.ahlm@misu.su.se)

Received: 19 May 2017 - Discussion started: 29 May 2017

Revised: 27 September 2017 - Accepted: 6 October 2017 - Published: 6 November 2017

\begin{abstract}
Marine cloud brightening through sea spray injection has been proposed as a climate engineering method for avoiding the most severe consequences of global warming. A limitation of most of the previous modelling studies on marine cloud brightening is that they have either considered individual models or only investigated the effects of a specific increase in the number of cloud droplets. Here we present results from coordinated simulations with three Earth system models (ESMs) participating in the Geoengineering Model Intercomparison Project (GeoMIP) G4sea-salt experiment. Injection rates of accumulation-mode sea spray aerosol particles over ocean between $30^{\circ} \mathrm{N}$ and $30^{\circ} \mathrm{S}$ are set in each model to generate a global-mean effective radiative forcing (ERF) of $-2.0 \mathrm{~W} \mathrm{~m}^{-2}$ at the top of the atmosphere. We find that the injection increases the cloud droplet number concentration in lower layers, reduces the cloud-top effective droplet radius, and increases the cloud optical depth over the injection area. We also find, however, that the global-mean clear-sky ERF by the injected particles is as large as the corresponding total ERF in all three ESMs, indicating a large potential of the aerosol direct effect in regions of low cloudiness. The largest enhancement in ERF due to the presence of clouds occur as expected in the subtropical stratocumulus regions off the west coasts of the American and African continents. However, outside these regions, the ERF is in general equally large in cloudy and clear-sky conditions. These findings suggest a more important role of the aerosol direct effect in sea spray climate engineering than previously thought.
\end{abstract}

\section{Introduction}

Attempts to lower global emissions of $\mathrm{CO}_{2}$ have so far been mostly unsuccessful. As a result, climate engineering is increasingly being discussed as a way to dampen the climate effects of anthropogenic greenhouse gas emissions. One of the climate engineering methods proposed to counteract global warming is by seeding marine clouds with sea spray aerosol to enhance the number of activated cloud droplets (Latham, 1990). It has been suggested that this could be generated in practice through the use of unmanned wind-driven vessels spraying sea water into the air (Salter et al., 2008), and as the sea water evaporates it would leave behind sea spray aerosol particles which may be transported into the cloud layer. If the cloud liquid water content in the seeded clouds remains constant, an increase in the cloud droplet number concentration (CDNC) will lead to a reduction in cloud droplet size and thereby an increase in droplet surface area and cloud albedo (Twomey, 1977). Increasing the cloud albedo through this indirect effect of the injected particles is the original idea of sea spray climate engineering, and this method is therefore often referred to as marine cloud brightening. The reduction in cloud droplet size following from an enhanced number of droplets may also lead to a second indirect effect in which the decreased size of the cloud droplets may reduce precipitation and thereby increase the cloud lifetime (Albrecht, 1989).

Earlier modelling studies on sea spray climate engineering investigated the radiative effects of marine cloud bright- 
ening mainly by prescribing an increase in CDNC (Latham et al., 2008; Jones et al., 2009; Rasch et al., 2009). However, more recent studies have included the sea salt injection process and the activation of the injected particles to cloud droplets, thereby taking into account radiative effects of both activated cloud droplets and non-activated particles (Jones and Haywood, 2012; Partanen et al., 2012; Alterskjær et al., 2013). As a result, sea spray climate engineering is now sometimes referred to as marine sky brightening (Muri et al., 2015), as it may include radiative impacts of injected particles both through cloud brightening (the aerosol indirect effect) and due to increased scattering of solar radiation outside clouds (the aerosol direct effect). One of the more recent modelling studies on sea spray climate engineering applied emission patterns to maximize either the direct or the indirect radiative effect of the injected particles, limiting the emission area in both cases to $10 \%$ of the ocean (Jones and Haywood, 2012). In that study, maximizing the indirect effect generated the largest radiative impact and resulted in the largest cooling, but it should be noted that the direct effect was of comparable magnitude to that of the indirect effect within the region specified to maximize the aerosol indirect effect. In another recent modelling study, the aerosol direct effect was estimated to contribute $29 \%$ to the total radiative forcing when sea spray climate engineering was assumed to take place over the global oceans (Partanen et al., 2012). In contrast, one recent study indicated a dominant contribution from the aerosol direct effect to the total radiative forcing (Kravitz et al., 2013).

A weakness of almost all of the previous studies on sea spray climate engineering is that they have only considered individual models. It is therefore uncertain to what extent the results in many of the previous studies are robust, considering the differences in parameterizations across models of, for example, clouds and their interaction with aerosols. Furthermore, results from individual model studies in the past are generally not directly comparable because of discrepancies in the model set-up or in the details of what was actually simulated. Therefore, the idea behind the Geoengineering Model Intercomparison Project (GeoMIP) (Kravitz et al., 2011, 2013) is that model experiments should be standardized, and that an ensemble of multiple Earth system models (ESMs) should be executed for a number of climate engineering experiments. By the use of such ensembles, it is possible to estimate an uncertainty in the predicted climate response.

In this study we use three fully coupled atmosphereocean ESMs and run the GeoMIP G4sea-salt experiment (see Kravitz et al., 2013, and Sect. 2) focusing on the response of Earth's radiation balance to injection of sea salt particles, both in clear-sky conditions and from changes in cloud properties.

\section{Methods}

\subsection{Models}

Coupled state-of-the-art Earth system models provide the best tools for assessing the climate response to solar climate engineering. Three fully coupled ESMs - NorESM1M (Bentsen et al., 2013), GISS-E2-R (Schmidt et al., 2014), and HadGEM2-ES (Collins et al., 2011) - were used in this study. For the atmospheric component, NorESM1-M runs at $1.9^{\circ} \times 2.5^{\circ}$ in the horizontal with 26 vertical layers, GISSE2-R runs at $2^{\circ} \times 2.5^{\circ}$ in the horizontal with 20 vertical layers, and HadGEM2-ES runs at $1.3^{\circ} \times 1.9^{\circ}$ in the horizontal with 38 vertical layers. For the ocean component, NorESM1$\mathrm{M}$ runs at $\sim 1^{\circ} \times 1^{\circ}$ in the horizontal with 70 layers, GISSE2-R runs at $1^{\circ} \times 1.3^{\circ}$ in the horizontal with 32 layers, and HadGEM2-ES runs at $1^{\circ} \times 1^{\circ}$ in the horizontal between the poles and $30^{\circ}$ latitude with the meridional resolution increasing smoothly to $1 / 3^{\circ}$ at the Equator and with 40 vertical layers.

The treatment of the natural emissions of sea salt is prognostic in NorESM1-M and GISS-E2-R, with emission fluxes depending on wind speed and sea surface temperatures in NorESM1-M (Struthers et al., 2011), and on wind speed only in GISS-E2-R (Monahan et al., 1986). HadGEM2-ES uses a diagnostic treatment of natural sea salt aerosol number concentration with concentrations depending on wind speed (Jones et al., 2001). Hygroscopic growth of aerosol particles is accounted for in all three models, and this process affects dry removal rates as well as aerosol-radiation interactions. In NorESM1-M, hygroscopic growth is treated as described by Seland et al. (2008), by applying the form of Köhler equation given in Kirkevåg and Iversen (2002). In GISS-E2-R, uptake of water by hygroscopic species such as sea salt and sulfate is parameterized in terms in terms of an external mixture of the dry aerosol and a pure water aerosol with sizes set to reproduce the extinction efficiency and asymmetry parameters of the solute aerosol at the laboratory wavelength of $633 \mathrm{~nm}$ (Schmidt et al., 2006). In HadGEM2-ES, hygroscopic growth of sea salt, and sulfate is modelled following Fitzgerald (1975). NorESM1-M and GISS-E2-R have fully prognostic treatment of CDNC. In HadGEM2-ES, the CDNC is a function of sulfate, sea salt and carbonaceous particle number concentrations (Jones and Haywood, 2012).

Dry deposition of aerosol particles in all three models is parameterized using resistance schemes analogous to electrical resistance (e.g. Seinfeld and Pandis, 1998). The dry deposition velocity thus depends on particle size. Gravitational settling is included in the calculation of the dry deposition velocity. Rainout is determined by autoconversion in all models and includes re-evaporation of precipitation. Wet deposition in NorESM1-M is parameterized as in Iversen and Seland (2002), with an in-cloud scavenging coefficient defined as the mass fraction of the aerosol mode within the cloud droplet. Wet deposition in GISS-E2-R and HadGEM2-ES are 
described in more detail by Koch et al. (2007) and Bellouin et al. (2011), respectively.

\subsection{Experiments}

The following experiments are analysed in this study:

1. RCP4.5: Representative Concentration Pathway 4.5 (Meinshausen et al., 2011), where the total radiative forcing reaches $4.5 \mathrm{~W} \mathrm{~m}^{-2}$ in year 2100 , following the CMIP5 protocol (Taylor et al., 2011).

2. G4sea-salt: this experiment follows the experimental design of the Geoengineering Model Intercomparison Project (GeoMIP) G4sea-salt experiment (Kravitz et al., 2013). Sea spray climate engineering is implemented on top of an RCP4.5 scenario to generate a top-of-theatmosphere (TOA) global-mean effective radiative forcing (ERF) of $-2.0 \mathrm{~W} \mathrm{~m}^{-2}$. Although sea spray aerosol consists of both sea salt and ocean-derived organic species (e.g. de Leeuw et al., 2011), here we only consider the injection of sea salt particles. The injection is applied at a constant rate in the marine boundary layer between $30^{\circ} \mathrm{N}$ and $30^{\circ} \mathrm{S}$, as this is the area where the largest radiative effects have been predicted from sea salt seeding (Alterskjær et al., 2012; Jones and Haywood, 2012; Kravitz et al., 2013). The sea salt is injected in the lowest model layer of the ESMs, and the injection flux is equally large for each grid cell over the ocean within this latitudinal band. Sea spray climate engineering starts in year 2020 and continues until year 2070 , whereupon the simulations are carried on for another 20 years such that the termination effect can be assessed.

3. Fixed sea surface temperature (SST) experiments: the G4sea-salt and RCP4.5 experiments were simulated also with fixed SST, as taken from year 2020 of the RCP4.5 simulation (Kravitz et al., 2013). All other forcing was kept the same as in year 2020 of RCP4.5, with the only difference being increased sea salt emissions. The experiments were run for 10 years for each model in order to determine the injection rate of sea salt aerosol in each model required to generate a global-mean ERF of $-2.0 \mathrm{~W} \mathrm{~m}^{-2}$ compared to the RCP4.5 scenario. The ERF by the injected particles in these simulations is equal to the change in net total radiation (shortwave + longwave) at the TOA between the G4sea-salt simulation (with sea salt injection) and the RCP4.5 simulation (without sea salt injection). The injection rates required to generate the $-2.0 \mathrm{~W} \mathrm{~m}^{-2} \mathrm{ERF}$ at the TOA were then applied in the fully coupled simulations between years 2020 and 2070

The injected sea salt particles within the G4sea-salt experiment have a median dry radius of $0.13 \mu \mathrm{m}$ in NorESM1$\mathrm{M}, 0.44 \mu \mathrm{m}$ in GISS-E2-R, and $0.10 \mu \mathrm{m}$ in HadGEM2-
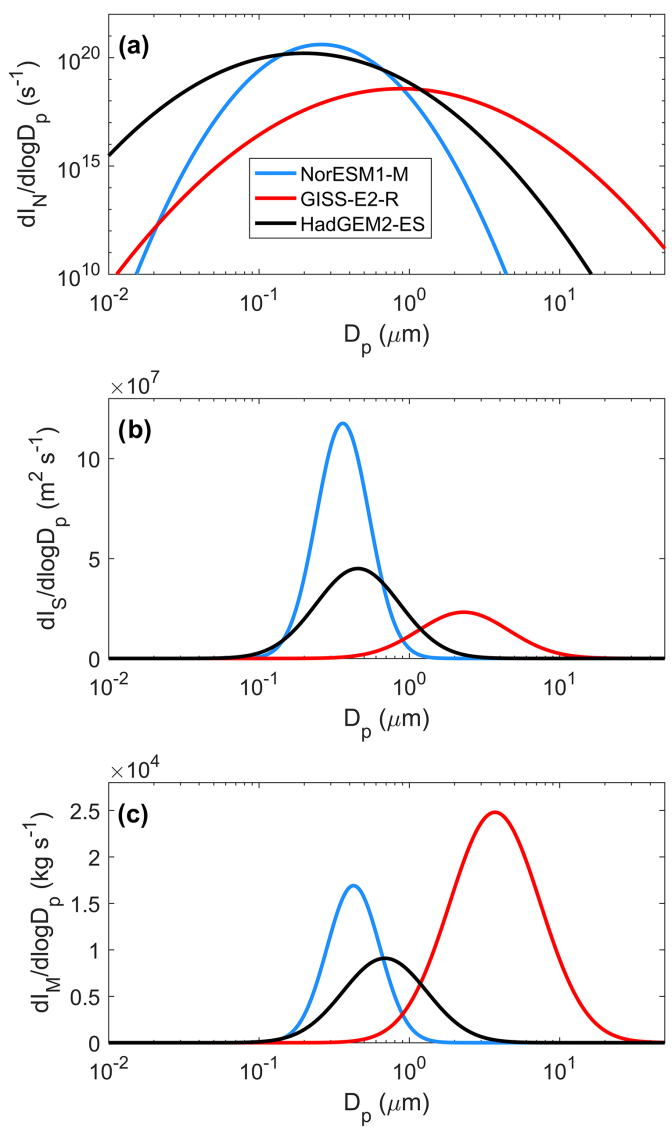

Figure 1. Size distributions for total sea salt injections $\left(30^{\circ} \mathrm{N}\right.$ and $30^{\circ} \mathrm{S}$ ) of (a) particle number $I_{\mathrm{N}}$, (b) particle surface area $I_{\mathrm{S}}$, and (c) particle mass $I_{\mathrm{M}}$ for NorESM1-M (blue), GISS-E2-R (red), and HadGEM2-ES (black).

ES, equal to the median dry radius of the naturally emitted accumulation-mode sea spray particles in each model. The geometric standard deviations of the size distributions are $1.5,2.0$, and 1.9 for NorESM1-M, GISS-E2-R, and HadGEM2-ES, respectively. Size distributions of the injected sea salt particles are shown in Fig. 1 for particle number (Fig. 1a), particle surface area (Fig. 1b), and particle mass (Fig. 1c). These size distributions represent the total injection per second within the injection area.

There is large uncertainty in which particle size would be optimal for sea spray climate engineering. The mass scattering efficiency of $\mathrm{NaCl}$ particles with a refractive index of 1.544 at a wavelength of $550 \mathrm{~nm}$ has its maximum for a particle radius of $\sim 0.3 \mu \mathrm{m}$ (Seinfeld and Pandis, 1998). However, within the atmosphere hygroscopic growth and condensation of other species like sulfuric acid will modify the size of the injected particles, which will influence the aerosol direct effect. Latham et al. (2008) estimated that the optimal sea spray dry radius for cloud seeding is in the range of 0.10 to $0.50 \mu \mathrm{m}$. In contrast, Connolly et al. (2014) found using a parcel model that injection of Aitken-mode particles would 


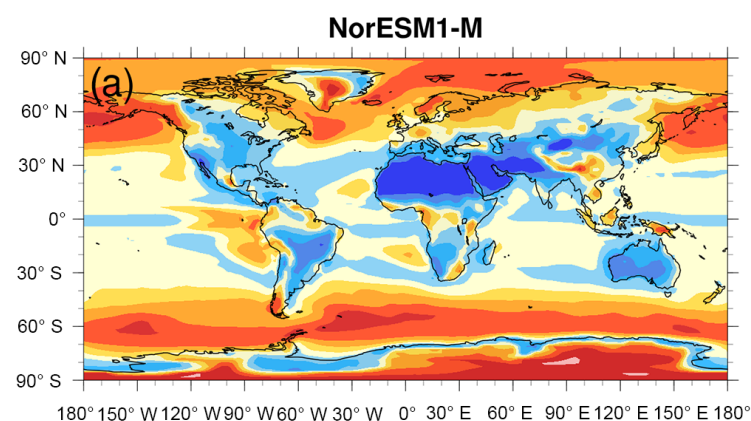

HadGEM2-ES

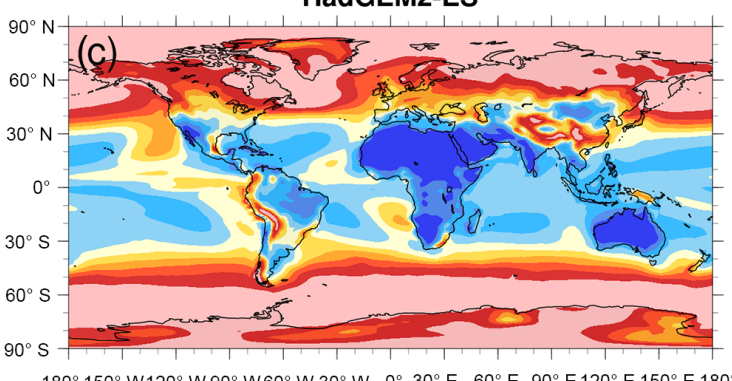

$180^{\circ} 150^{\circ} \mathrm{W} 120^{\circ} \mathrm{W} 90^{\circ} \mathrm{W} 60^{\circ} \mathrm{W} 30^{\circ} \mathrm{W} 0^{\circ} 30^{\circ} \mathrm{E} 60^{\circ} \mathrm{E} 90^{\circ} \mathrm{E} 120^{\circ} \mathrm{E} 150^{\circ} \mathrm{E} 180^{\circ}$

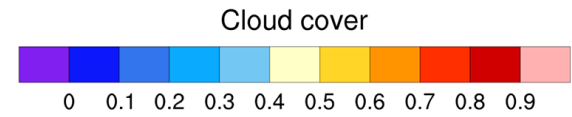

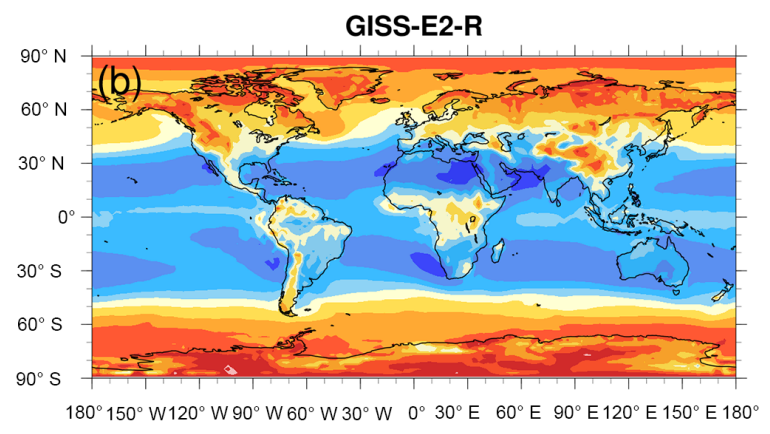

Figure 2. Cloud fraction for low clouds averaged over 2020-2030 within the RCP4.5 scenario for (a) NorESM1-M, (b) GISS-E2-R, and (c) HadGEM2-ES. Cloud fractions have been estimated by assuming random overlapping for layers below $850 \mathrm{hPa}(\mathbf{a}, \mathbf{c})$ and below $600 \mathrm{hPa}(\mathbf{b})$.

be most efficient, as hygroscopic growth of such injected sea salt particles was shown to significantly enhance the albedo of the cloud layer. Injection of Aitken-mode particles, however, generated a positive forcing in NorESM1-M in a previous study by Alterskjær and Kristjánsson (2013), caused by a strong competition effect combined with high critical supersaturation of Aitken-mode particles. Representing sea spray climate engineering in our simulations obviously requires injections that produce a negative forcing. The size of the injected particles in this study is in the same size range as most previous ESM studies on sea spray climate engineering that simulate the aerosol injection (e.g. Alterskjær et al., 2012, 2013; Jones and Haywood, 2012; Korhonen et al., 2010; Muri et al., 2015; and Wang et al., 2011). It should also be mentioned that extensive measurements show that organics contribute substantially to the composition of sea spray aerosol, and in many areas is even the dominant constituent (e.g. de Leeuw et al., 2011). As sea spray climate engineering would likely produce particles with a similar composition as natural sea spray, the injected particles would thus need to be larger to activate to cloud droplets compared to when assuming pure sea salt as in the study by Connolly et al. (2014). In particular, the presence of organics suppresses hygroscopic growth compared to pure sea salt, which may be relevant since Connolly et al. (2014) found that interstitial particles play an important role in controlling the albedo in their study.

The fully coupled RCP4.5 simulations include two realizations with NorESM1-M, three realizations with GISSE2-R, and four realizations with HadGEM2-ES. The fully coupled G4sea-salt simulations include two realizations with NorESM1-M, three realizations with GISS-E2-R, and one realization with HadGEM2-ES.

\section{Results and discussion}

A key variable in the models when considering sea spray climate engineering is the amount of low clouds over the ocean, in particular subtropical stratocumulus clouds off the west coasts of North America, South America, and southern and northern Africa. These regions have been assessed to be most susceptible to brightening (Salter et al., 2008; Alterskjær et al., 2012; Jones and Haywood, 2012). Figure 2 shows the low-level cloud fraction below $850 \mathrm{hPa}$ for NorESM1M (Fig. 2a) and HadGEM2-ES (Fig. 2c), and below $600 \mathrm{hPa}$ for GISS-E2-R (Fig. 2b), averaged over years 2020-2030 in the RCP4.5 scenario. Here we use the assumption of random overlapping cloud layers for the estimates of the cloud cover. NorESM1-M (Fig. 2a) and HadGEM2-ES (Fig. 2c) capture the maxima in low-level cloud cover associated with the sub- 

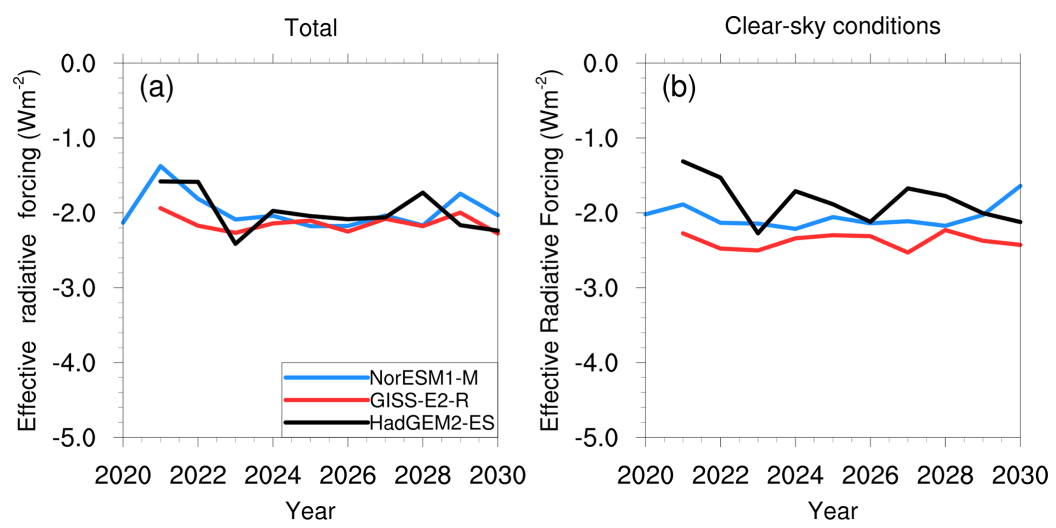

Figure 3. Global-mean TOA effective radiative forcing of the injected particles in total (a) and in clear-sky conditions (b). The ERF for each model was determined from 10-year simulations with fixed SST with and without sea salt injection.

tropical high-pressure cells in the eastern parts of the Pacific Ocean and the Atlantic Ocean (e.g. Rossow and Schiffer, 1999). The reason for including layers higher than $850 \mathrm{hPa}$ in the estimate of low-level cloud cover for GISS-E2-R is that for the region west of Peru the model reaches its maximum in cloud cover slightly above $850 \mathrm{hPa}$. From Fig. 2 it is clear that the low-cloud amounts over tropical and subtropical ocean are considerably lower in GISS-E2-R than in NorESM1-M and HadGEM2-ES, in particular when it comes to stratocumulus clouds in the subtropical high-pressure cells in the eastern parts of the Pacific Ocean and Atlantic Ocean. This needs to be taken into account in the assessment of the impact of sea spray climate engineering in GISS-E2-R.

\subsection{Effective radiative forcing by the injected particles}

The sea salt injection rates between $30^{\circ} \mathrm{N}$ and $30^{\circ} \mathrm{S}$ required to generate a global-mean ERF of $-2.0 \mathrm{Wm}^{-2}$ at the TOA are $250 \mathrm{Tg} \mathrm{yr}^{-1}$ in NorESM1-M, $590 \mathrm{Tg} \mathrm{yr}^{-1}$ in GISS-E2-R, and $200 \mathrm{Tg} \mathrm{yr}^{-1}$ in HadGEM2-ES. The fact that GISS-E2-R requires a larger injection rate than the two other ESMs is likely due to the larger dry radius of the injected particles in GISS-E2-R $(0.44 \mu \mathrm{m})$ than in NorESM1-M $(0.13 \mu \mathrm{m})$ and HadGEM2-ES $(0.10 \mu \mathrm{m})$. This means that a specific injection rate in GISS-E2-R results in fewer particles than in the two other ESMs (Fig. 1a). The smaller amount of low clouds in GISS-E2-R (Fig. 2b) may also be a contributing factor to the larger injection rates required in this model. The injection rates in this study are close to the rate reported by Partanen et al. (2012), who obtained a $-5.1 \mathrm{~W} \mathrm{~m}^{-2}$ global-mean ERF in the aerosol-climate model ECHAM5.5-HAM2 from wind-speed-dependent global sea salt injections at a rate of $440 \mathrm{Tg} \mathrm{yr}^{-1}$. Our injection rates are also similar to those reported by Alterskjær et al. (2013), who applied gradually increasing sea salt injection rates between $30^{\circ} \mathrm{N}$ and $30^{\circ} \mathrm{S}$ in three different ESMs to keep the TOA radiative forcing of an RCP4.5 scenario at the 2020 level for 50 years. The radiative forcing change within the RCP4.5 scenario between
2020 and 2070 is $+1.64 \mathrm{~W} \mathrm{~m}^{-2}$. During the last decade of their simulations, the injection rates required varied between 266 and $560 \mathrm{Tg} \mathrm{yr}^{-1}$ across their three models.

The global-mean ERF by the injected sea salt particles, for the rates given above, is relatively constant at $-2.0 \mathrm{~W} \mathrm{~m}^{-2}$ throughout the 10-year fixed SST simulation in all three ESMs (Fig. 3a). The radiative fluxes in the ESMs are calculated also for clear-sky conditions. These clear-sky radiative fluxes can be used to determine the clear-sky global-mean ERF (Fig. 3b). This variable is not equal to the aerosol direct effect of the injected particles, because the aerosol direct effect is larger in clear-sky conditions than when clouds are present. This is because most of the injected particles are located below cloud base when clouds are present, which reduces the aerosol direct effect due to the high albedo of most clouds. Nevertheless, it is interesting to note that the clearsky global-mean ERF (Fig. 3b) is almost equal to the total global-mean ERF (Fig. 3a) throughout the 10 years in the three ESMs, indicating a large potential of the aerosol direct effect in regions of low cloudiness. Although we cannot estimate the contribution of the aerosol direct effect to the total ERF from Fig. 3, it is evident that sea spray climate engineering can be effective even without clouds.

The clear-sky ERF by the injected particles in Fig. $3 b$ is of comparable magnitude for the three models, despite the higher sea salt mass injection rates and larger size of the injected particles in GISS-E2-R compared to the other two models. The surface area size distribution (Fig. 1b) is closely related to the amount of light scattered by the sea salt particles and thereby the clear-sky ERF in Fig. 3b. For a full description of Mie scattering, however, one also needs to take into account variations in the scattering coefficient with particle size, which is done in the radiative transfer calculations in the models. The total particle number injections (integrated over the particle number size distributions in Fig. 1a) are $1.8 \times 10^{20}, 2.7 \times 10^{18}$, and $1.1 \times 10^{20} \mathrm{~s}^{-1}$ for NorESM1M, GISS-E2-R, and HadGEM2-ES; thus the number of injections is almost 2 orders of magnitude smaller in GISS- 

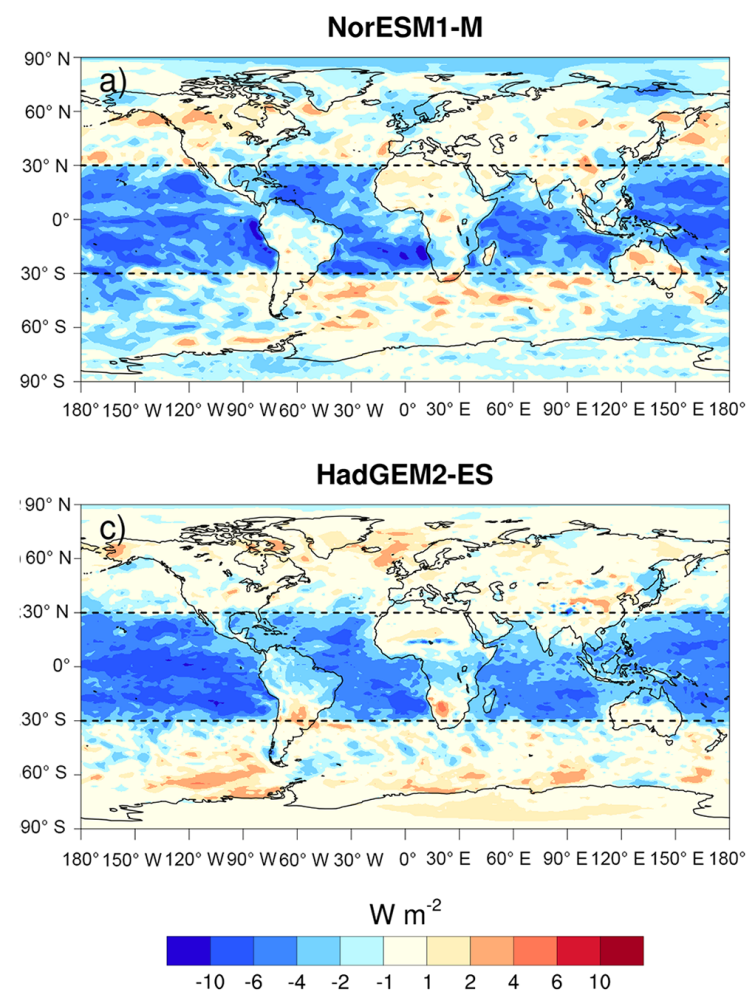

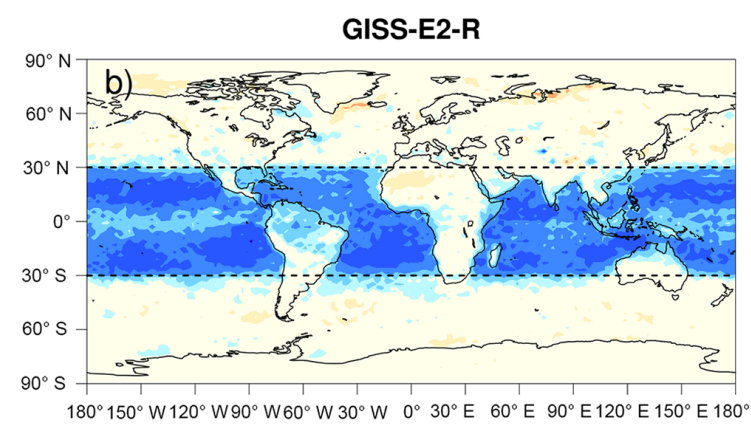

$180^{\circ} 150^{\circ} \mathrm{W} 120^{\circ} \mathrm{W} 90^{\circ} \mathrm{W} 60^{\circ} \mathrm{W} 30^{\circ} \mathrm{W} 0^{\circ} 30^{\circ} \mathrm{E} 60^{\circ} \mathrm{E} 90^{\circ} \mathrm{E} 120^{\circ} \mathrm{E} 150^{\circ} \mathrm{E} 180^{\circ}$

Figure 4. TOA mean effective radiative forcing over the 10 years of simulation with fixed SST for (a) NorESM1-M, (b) GISS-E2-R, and (c) HadGEM2-ES.

E2-R compared to the other models. The corresponding particle surface injections (integrated over the particle surface distributions in Fig. 1b) are $5.2 \times 10^{7}, 1.7 \times 10^{7}$, and $3.1 \times$ $10^{7} \mathrm{~m}^{2} \mathrm{~s}^{-1}$ for NorESM1-M, GISS-E2-R, and HadGEM2ES. Thus, although the difference in total particle number injection between GISS-E2-R and the other two models is large, the difference in total particle surface area injection is considerably smaller. Hygroscopic growth is accounted for in all the three models (Sect. 2.1), and this process will modify the injected particle size distributions in the atmosphere, since the relative humidity within the injection area is generally above the deliquescence relative humidity for sea salt. The light-scattering enhancement factor (e.g. Titos et al., 2016) describes the relative increase in aerosol light scattering at a certain relative humidity compared to dry conditions. This parameter is not diagnosed in the models for the injected sea salt particles, but decreases with increasing particle dry diameter for a certain relative humidity (e.g. Zieger et al., 2013). This means that hygroscopic growth of the injected particles is expected to generate a larger increase in clear-sky ERF in NorESM1-M and HadGEM2-ES than in GISS-E2-R, since the injected particles are larger in GISS-E2-R than in the two other models. The main reason that sea salt injections in GISS-E2-R still generates a clear-sky ERF as large as the other two models, or even slightly larger (Fig. 3b), is likely due to GISS-E2-R having the lowest background clear-sky atmospheric optical depth of the three models (not shown). This means that GISS-E2-R is more sensitive to injections than the two other models.

The effective radiative forcing by the injected particles at the TOA varies spatially between -2.0 and $-10 \mathrm{Wm}^{-2}$ across the injection area in the three ESMs (Fig. 4). The mean values over the injection area are $-4.3 \mathrm{~W} \mathrm{~m}^{-2}$ in NorESM1-M, $-4.9 \mathrm{~W} \mathrm{~m}^{-2}$ in GISS-E2-R, and $-4.7 \mathrm{~W} \mathrm{~m}^{-2}$ in HadGEM2-ES. The injection area here, and for later calculations, represents all grid cells over ocean between $30^{\circ} \mathrm{N}$ and $30^{\circ} \mathrm{S}$. In NorESM1-M (Fig. 4a), maximum ERF appears in the stratocumulus regions off the west coasts of northern South America and southern Africa (Fig. 2a), locally exceeding $-10 \mathrm{~W} \mathrm{~m}^{-2}$. This means that the ERF over these regions is a factor of 2-3 larger than the average over the injection area. The location of these maxima is in agreement with the studies by Jones and Haywood (2012) and Partanen et al. (2012), who observed a strong aerosol indirect effect in these areas from sea spray climate engineering. The ERF maximum off the west coast of southern Africa is also pronounced in HadGEM2-ES (Fig. 4c), although weaker in forcing than in NorESM1-M. In addition, there are maxima in ERF in the marine stratocumulus regions west of northern Africa and west of Australia for both NorESM1-M and HadGEM2-ES. Jones and Haywood (2012) saw a strong 

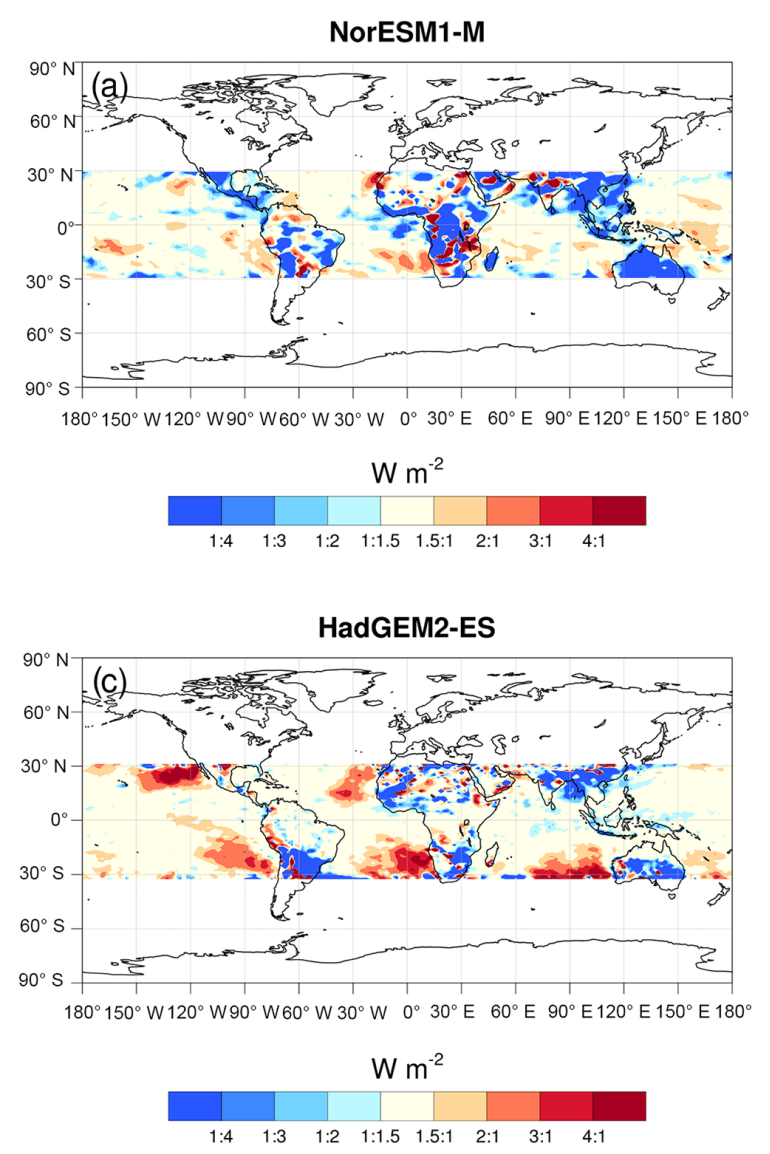
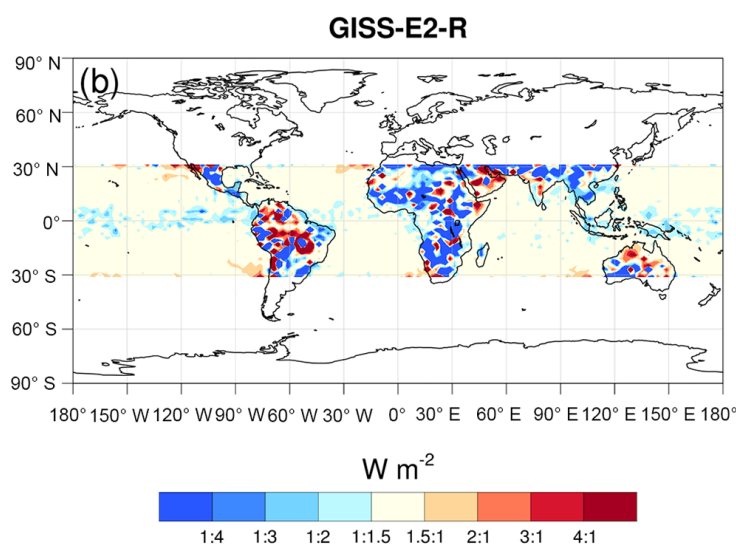

Figure 5. The ratio of the total ERF to the clear-sky ERF at the TOA averaged over the 10 years of simulation with fixed SST for (a) NorESM1-M, (b) GISS-E2-R, and (c) HadGEM2-ES.

aerosol indirect effect from sea spray climate engineering in these regions in the HadGEM2-ES model.

Although the effective radiative forcing by the injected particles in NorESM1-M and HadGEM2-ES is at a maximum over some of the marine subtropical stratocumulus regions previously identified as optimal for marine cloud brightening, the ERFs in Fig. 4 are not as dominated by these regions as in the study by Partanen et al. (2012) with ECHAM5.5-HAM2. In that study, the maximum ERF of their sea spray climate engineering exceeded $-30 \mathrm{~W} \mathrm{~m}^{-2}$ in the stratocumulus regions west of Peru and southern Africa, whereas the mean ERF outside these regions was around $-5 \mathrm{~W} \mathrm{~m}^{-2}$. This means that the ERF by the injected particles in the subtropical stratocumulus regions was more than a factor of 6 higher than the typical ERF outside these regions. Such a large difference in ERF between subtropical stratocumulus regions and other regions within the injection area is not seen here. For NorESM1-M and HadGEM2-ES the sea salt injection also generates a strong ERF over large regions of the central and western parts of the Pacific Ocean, where a low cloud-weighted susceptibility to sea salt injections (Alterskjær et al., 2012) and a strong aerosol direct effect from sea spray climate engineering (Jones and Haywood, 2012) have been identified. The correlation between the strength of the effective radiative forcing and low-level cloud cover (as defined in Fig. 2), when including all grid cells over ocean within the injection area, is weak for these two models (the Pearson correlation coefficient $r$ is equal to 0.28 and 0.16 for NorESM1-M, and HadGEM2-ES respectively). Thus, over the injection area as a whole, the presence of low-level clouds gives no clear advantage for obtaining a large ERF from sea spray climate engineering.

Although GISS-E2-R (Fig. 4b) has maxima in ERF in the same subtropical stratocumulus regions as the other two models, there is less horizontal variability in ERF in GISS-E2-R. An exception is the Intertropical Convergence Zone (ITCZ), where the ERF is considerably weaker, likely due to the large amounts of high clouds in these regions (not shown). The presence of middle to high-level clouds is not optimal for sea spray climate engineering as these clouds block out some of the incoming solar radiation and make a negligible contribution to the aerosol indirect effect. A weaker ERF along the ITCZ can be seen to some extent also over the Pacific in NorESM1-M (Fig. 4a). The more homogeneous ERF field for GISS-E2-R compared to the two other models is likely due to the smaller amount of low- 


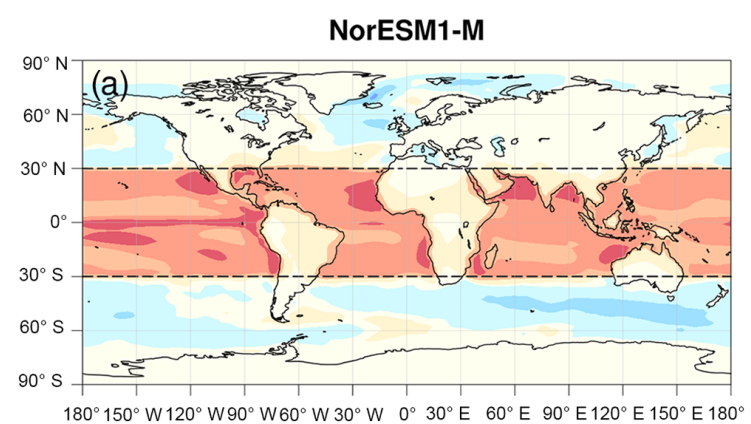

HadGEM2-ES
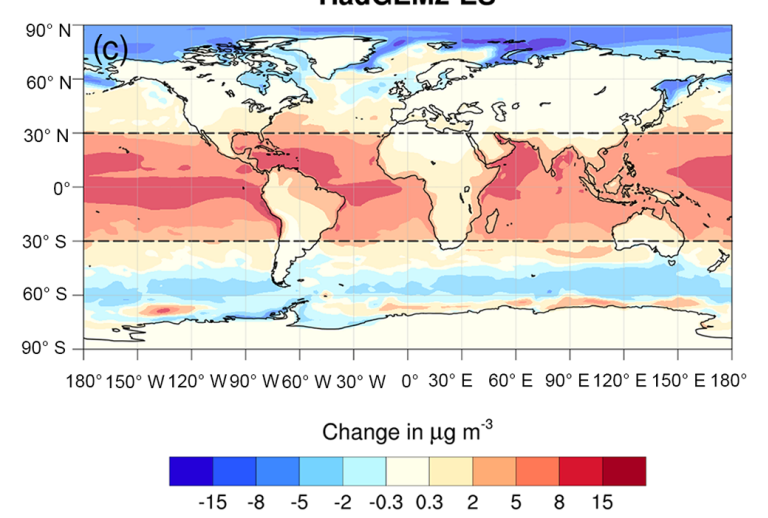

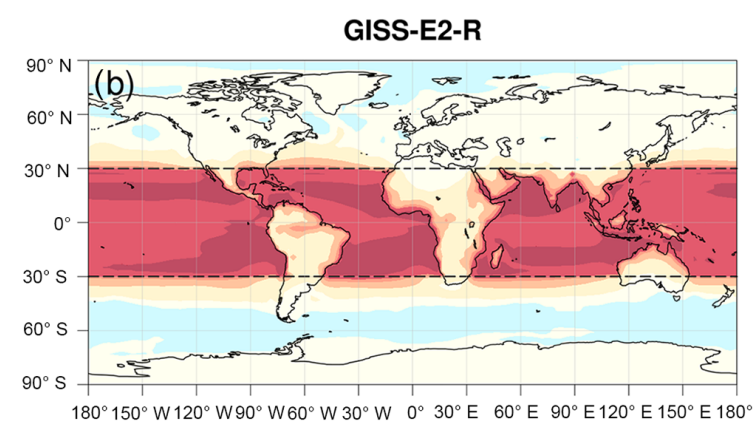

Figure 6. Mean difference in sea salt mass concentration in the lowest model layer between G4sea-salt and RCP4.5 averaged over 2035 and 2065, for (a) NorESM1-M, (b) GISS-E2-R, and (c) HadGEM2-ES.

level clouds in GISS-E2-R compared to the two other ESMs (Fig. 2). This means that the aerosol direct effect likely contributes more to the total ERF in GISS-E2-R, leading to fewer horizontal variations in ERF. This hypothesis of a low contribution of the aerosol indirect effect to the ERF in GISSE2-R is supported by the absence of correlation between the strength of the ERF and low-level cloud cover $(r=-0.10)$ for this model.

Figure 5 shows the ratio of the total ERF to clear-sky ERF at the TOA for each of the three models. This figure provides information on whether the clouds that are present increase the ERF by the injected particles compared to clear-sky conditions. Red-coloured areas indicate an increased ERF when clouds are present, and thereby an effective aerosol indirect effect, whereas blue-coloured regions indicate an enhanced ERF for clear-sky conditions. The impact of the subtropical stratocumulus clouds on the ERF by the injected particles, relative to clear-sky conditions, is largest in HadGEM2-ES (Fig. 5c), with the ratio of total ERF to clear-sky ERF locally being higher than $4: 1$ in regions west of California and Mexico, west of southern Africa, and west of Australia. In NorESM1-M (Fig. 5a), the corresponding enhancement in ERF in these regions due to the presence of low clouds is considerably smaller, although with a ratio locally above $3: 1$ in the Atlantic region west of northern Africa. In GISS-E2-R (Fig. 5b), the maximum values of the total ERF to clear-sky
ERF ratio appear in the same subtropical high-pressure regions as in the other models, although much less pronounced due to the smaller amount of low-level clouds in this model. For GISS-E2-R, there are regions along the ITCZ where the presence of clouds reduces the ERF by the injected particles (blue-coloured regions), likely due to the high presence of high-level clouds in these regions, as discussed above. Total ERF to clear-sky ERF ratios lower than one along the ITCZ indicate that the aerosol direct effect of the injected particles in clear-sky conditions is larger than the total radiative effect of the injected particles when clouds are present, and such ratios also appear locally in the other two ESMs.

In summary, the presence of low clouds in the subtropical high-pressure regions has the effect of increasing the ERF by the injected particles compared to clear-sky conditions, and this enhancement in ERF due to the aerosol indirect effect is most pronounced in HadGEM2-ES. However, in most other regions within the area of sea salt injection, the ratio of total ERF to clear-sky ERF is close to one in all the models, which indicates that the presence of clouds in most regions does not significantly increase the ERF compared to clear-sky conditions. This finding, together with the relatively small horizontal variability in ERF compared to Partanen et al. (2012) and weak or non-existent correlations between ERF and lowlevel cloud cover, suggests that the aerosol direct effect probably makes a larger contribution to the total ERF in this study 

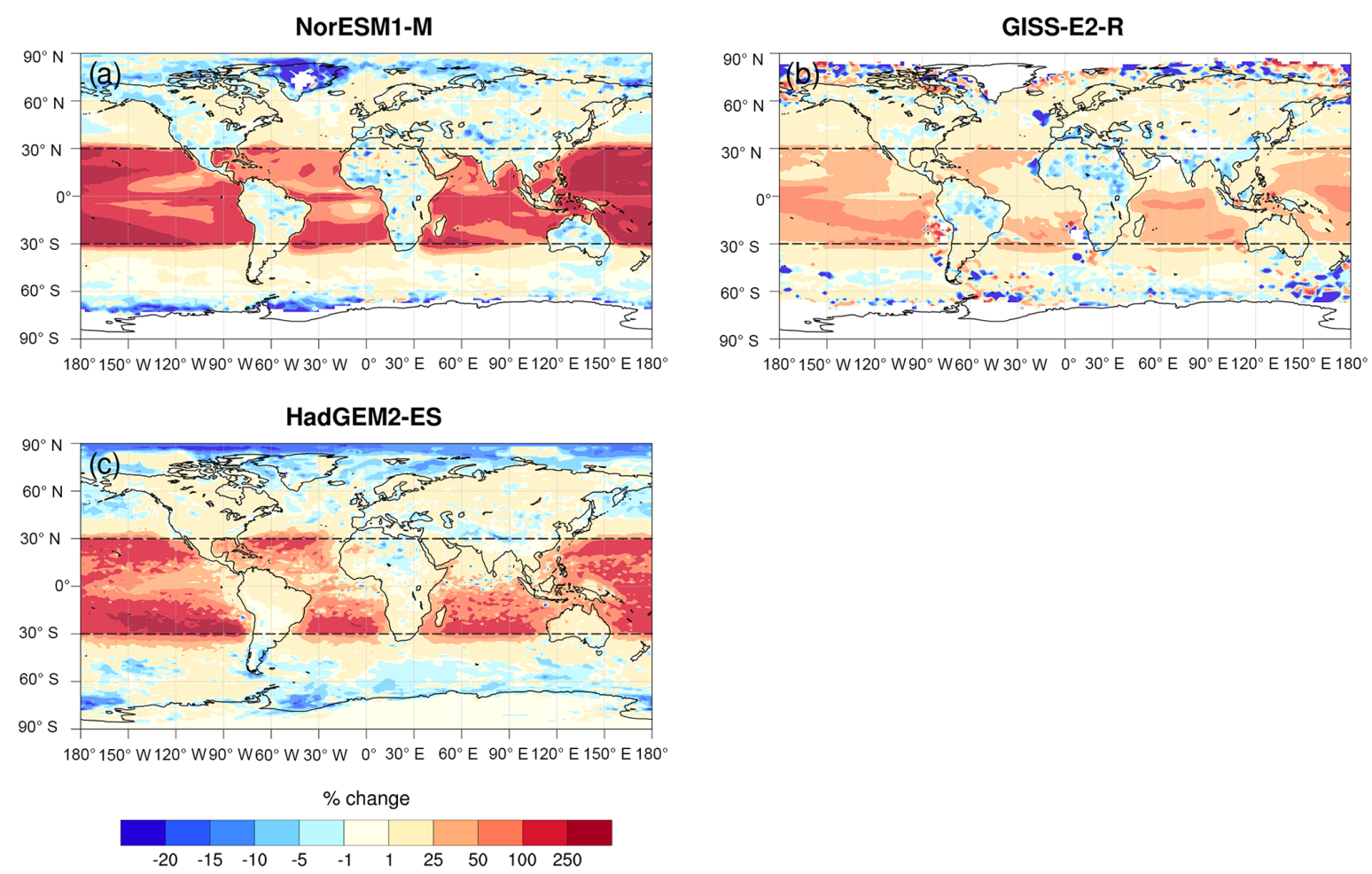

Figure 7. Mean relative change in CDNC due to sea salt injection for NorESM1-M (a), GISS-E2-R (b), and HadGEM2-ES (c). CDNC represents the cloud droplet number concentration within the model layer below $700 \mathrm{hPa}$ with maximum concentration, and the maps represent averages over 2035-2065.

compared to the study by Partanen et al. (2012), where the aerosol direct effect contributed $29 \%$ to the total ERF by sea spray climate engineering.

\subsection{Coupled simulations}

\subsubsection{Change in sea salt concentrations, cloud properties, and atmospheric circulation}

The injection rates generating a global-mean effective radiative forcing of $-2.0 \mathrm{~W} \mathrm{~m}^{-2}$ at the TOA in the simulations with fixed SST were applied in the fully coupled G4seasalt simulations between 2020 and 2070 in the three ESMs. These sea salt injections elevate the sea salt mass concentration within the injection area in all the models compared to the RCP4.5 scenario (Fig. 6). As mentioned in Sect. 3.1, the injection rate in GISS-E2-R was 2-3 times higher than in the two other ESMs, which explains the larger enhancement in mass concentration in GISS-E2-R compared to the other models. Despite equal sea salt flux increase in all grid cells within the injection area, there are large spatial variations in the increase in sea salt concentration in the lowest model layer in all the models. This is due to differences in precipitation, boundary layer depth, and horizontal and vertical transport across different regions. In NorESM1-M (Fig. 6a), comparatively large increases in sea salt concen- tration occur in the subtropical high-pressure regions. This is likely a combined effect of low precipitation, thin boundary layer, and generally little vertical mixing in these regions compared to regions with more convection. Similar patterns can be seen in GISS-E2-R (Fig. 6b) and in part in HadGEM2ES (Fig. 6c). HadGEM2-ES has further peak increases in sea salt concentrations closer to the Equator, which could indicate either more efficient aerosol transport equatorward by trade winds or less efficient wet removal in the ITCZ.

One of the advantages of simulating sea spray climate engineering in ESMs through sea salt aerosol emissions, compared to just increasing the CDNC, is that the cloud droplet activation process is taken into account. Previous studies have shown that injection of sea spray particles in some circumstances may actually reduce the CDNC due to increased competition for water vapour and reduced activation of background aerosol particles (Korhonen et al., 2010; Alterskjær et al., 2012). Alterskjær and Kristjánsson (2013) showed in a single-model study that while the injection of accumulation-mode particles increased the CDNC, the injections of Aitken- or coarse-mode particles could have the opposite effect with a reduction in CDNC. As mentioned in Sect. 2.2, the injected particles in this study are accumulation-mode particles with a median dry radius between 0.10 and $0.44 \mu \mathrm{m}$. The background CDNC within the injection area at an altitude of $\sim 1000 \mathrm{~m}$ averaged over 2035 

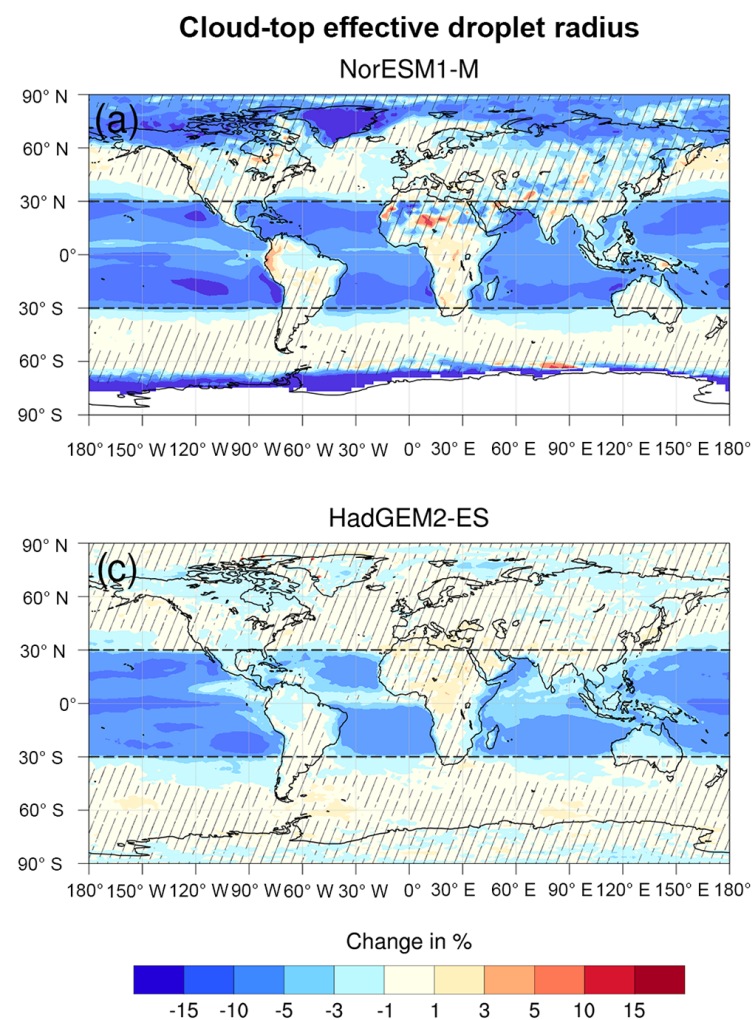

Cloud optical depth

NorESM1-M

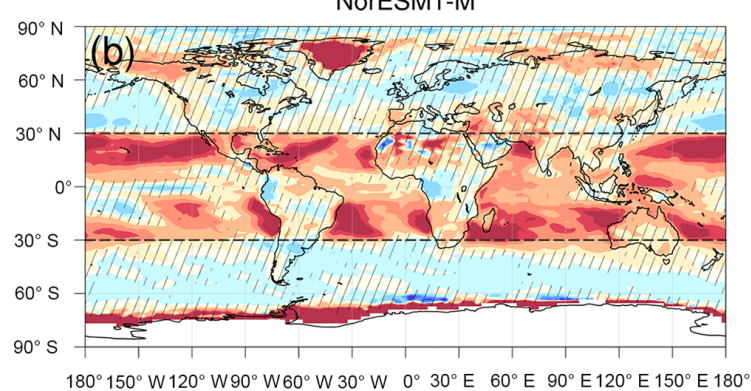

HadGEM2-ES

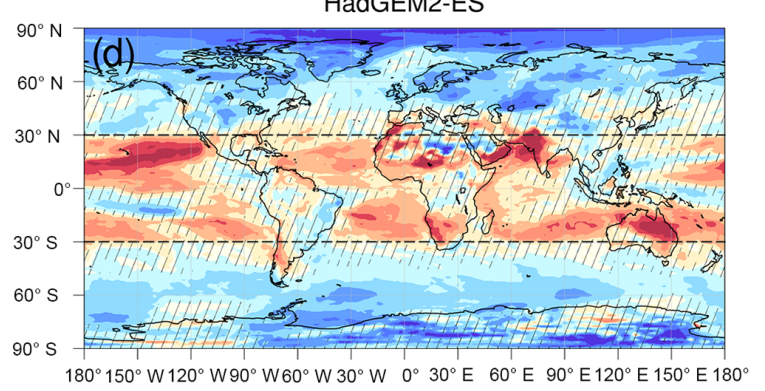

Change in \%

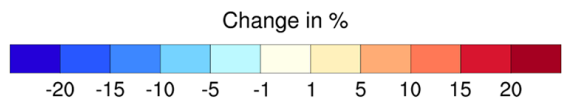

Figure 8. Mean relative change between G4sea-salt and RCP4.5 in cloud-top effective radius for NorESM1-M (a) and HadGEM2-ES (c) and in cloud optical depth for NorESM1-M (b) and HadGEM2-ES (d). The maps represent average change due to sea spray climate engineering over the period 2035-2065. Hatching denotes areas where changes are not significant at the $95 \%$ confidence level (Student $t$ test with respect to variance of annual mean values).

2065 for RCP4.5 varies for NorESM1-M from $10-20 \mathrm{~cm}^{-3}$ in the remote areas of Pacific and reaches a maximum of $\sim 100 \mathrm{~cm}^{-3}$ south of Mexico, west of northern Africa, southeast of China, and over the northern parts of the Indian Ocean. HadGEM2-ES has its maxima in CDNC at similar locations within the injection area. However, HadGEM2-ES has somewhat higher concentrations with a typical CDNC of $20-40 \mathrm{~cm}^{-3}$ in the remote Pacific Ocean and CDNC reaching $250 \mathrm{~cm}^{-3}$ at coastal locations closer to continental sources. GISS-E2-R has higher background CDNC than the other models, with concentrations of $50-100 \mathrm{~cm}^{-3}$ in the remote Pacific Ocean and concentrations higher than $1000 \mathrm{~cm}^{-3}$ in some coastal regions influenced by continental sources. Whereas NorESM1-M and HadGEM2-ES simulate CDNC close to estimates using MODIS (Moderate Resolution Imaging Spectroradiometer) data for cloud-top CDNC (e.g. Wood, 2012), GISS-E2-R predicts higher background CDNC than estimated from MODIS.

As shown in Fig. 7, the sea salt injection enhances the CDNC in lower layers within the whole injection area in all three ESMs. The mean percentage increase in CDNC within the injection area averaged for the period 2035-2065 (only grid cells over ocean included) is $153 \%$ in NorESM1-M, $42 \%$ in GISS-E2-R, and $89 \%$ in HadGEM2-ES (Table 1).
The largest enhancements in CDNC generally occur in regions where the background CDNC is low. The smaller percentage increase in CDNC in GISS-E2-R compared to the other two models is likely due to the higher background CDNC in GISS-E2-R. Over the Arctic region, there is a relatively large reduction in CDNC in NorESM1-M (Fig. 7a) and HadGEM2-ES (Fig. 7c). However, the CDNC in the Arctic region is as low as $\sim 1 \mathrm{~cm}^{-3}$, which implies that a very small absolute change in concentration can result in a large relative change in CDNC. The mechanism for the reduction of CDNC in the Arctic is likely related to the cooling induced by the sea salt: the cooling increases the sea ice cover in the Arctic and therefore reduces the source of natural sea salt and dimethyl sulfide (DMS), both of which cause a reduction in CDNC. The cooling also reduces the liquid water in the clouds, which may also contribute to the reduction in $\mathrm{CDNC}$, as this variable represents the number concentration of cloud liquid water particles in the air.

As expected, the cloud-top effective droplet radius, $r_{\mathrm{e}}$, is reduced due to the sea salt injection over the whole injection area (Fig. 8a and c). The mean reductions in $r_{\mathrm{e}}$ within the injection area are $-8.6 \%$ for NorESM1-M and $-6.4 \%$ for HadGEM2-ES ( $r_{\mathrm{e}}$ could not be diagnosed in GISS-E2-R) (Table 1). Although the change in cloud water path (vertically 

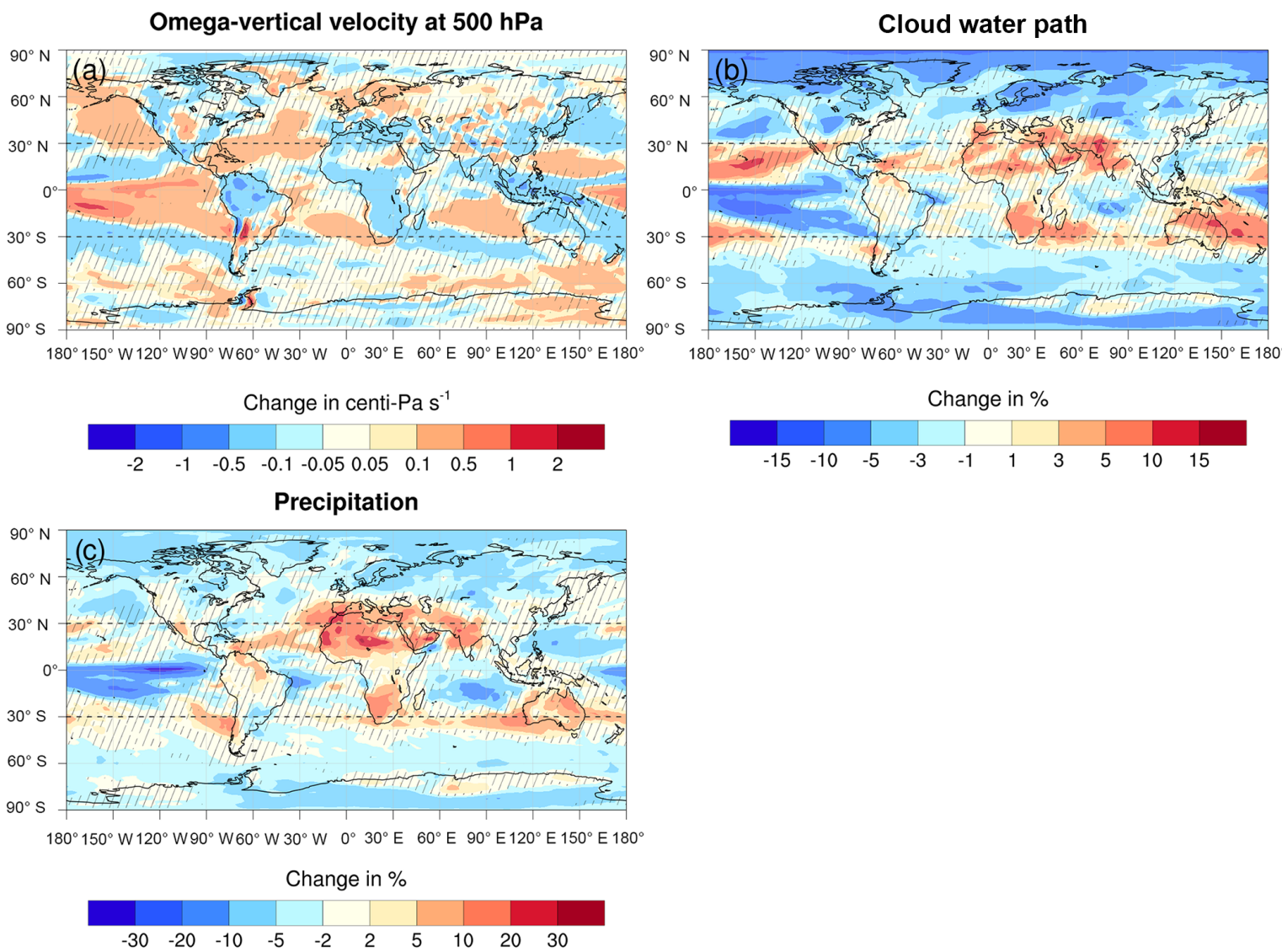

Figure 9. The multi-model mean difference between the G4sea-salt experiment and RCP4.5 averaged over years 2035-2065. The multimodel mean difference refers to the mean of all three models, NorESM1-M, GISS-E2, and HadGEM2-ES. Hatching denotes areas where the models disagree on the sign of the change. Change in (a) omega-vertical velocity at $500 \mathrm{hPa}$ (positive values corresponds to reduced upward motion) (centipascal per second), (b) cloud water path (vertically integrated cloud water content) (\%), and (c) precipitation rate (\%).

Table 1. Mean percentage changes in CDNC, cloud-top effective radius, cloud water path, cloud cover, cloud optical depth, precipitation, and surface air temperature $\left({ }^{\circ} \mathrm{C}\right)$ due to sea spray climate engineering. The changes represent the percentage difference between $\mathrm{G} 4$ sea-salt (with climate engineering) and RCP4.5 (without climate engineering) averaged over the period 2035-2065 for the injection area and globally. The change in CDNC represents the change in cloud droplet number concentration within the model layer below $700 \mathrm{hPa}$ with maximum concentration. Cloud-top effective radius and cloud optical depth could only be diagnosed for NorESM1-M and HadGEM2-ES. Cloud optical depth has been estimated using Eq. (1) (Stephens, 1978).

\begin{tabular}{lrr|rr|rr}
\hline & \multicolumn{2}{c|}{ NorESM1-M } & \multicolumn{2}{c|}{ GISS-E2-R } & \multicolumn{2}{r}{ HadGEM2-ES } \\
\cline { 2 - 6 } & $\begin{array}{r}\text { Injection } \\
\text { area mean }\end{array}$ & $\begin{array}{r}\text { Global } \\
\text { mean }\end{array}$ & $\begin{array}{r}\text { Injection } \\
\text { area mean }\end{array}$ & $\begin{array}{r}\text { Global } \\
\text { mean }\end{array}$ & $\begin{array}{r}\text { Injection } \\
\text { area mean }\end{array}$ & $\begin{array}{r}\text { Global } \\
\text { mean }\end{array}$ \\
\hline CDNC $(\%)$ & 153 & 65 & 28 & 15 & 89 & 36 \\
Cloud-top effective radius $(\%)$ & -8.6 & -5.5 & - & - & -6.4 & -3.8 \\
Cloud water path $(\%)$ & 0.53 & -0.11 & -1.3 & -1.9 & -1.3 & -1.4 \\
Cloud cover $(\%)$ & -2.8 & -2.0 & 0.05 & 0.11 & -0.11 & -0.24 \\
Cloud optical depth $(\%)$ & 10 & 5.9 & - & - & 5.7 & 2.1 \\
Precipitation $(\%)$ & -3.7 & -2.7 & -1.2 & -1.1 & -2.6 & -2.0 \\
Surface temperature $\left({ }^{\circ} \mathrm{C}\right)$ & -0.68 & -0.54 & -0.83 & -0.62 & -0.76 & -0.62 \\
\hline
\end{tabular}



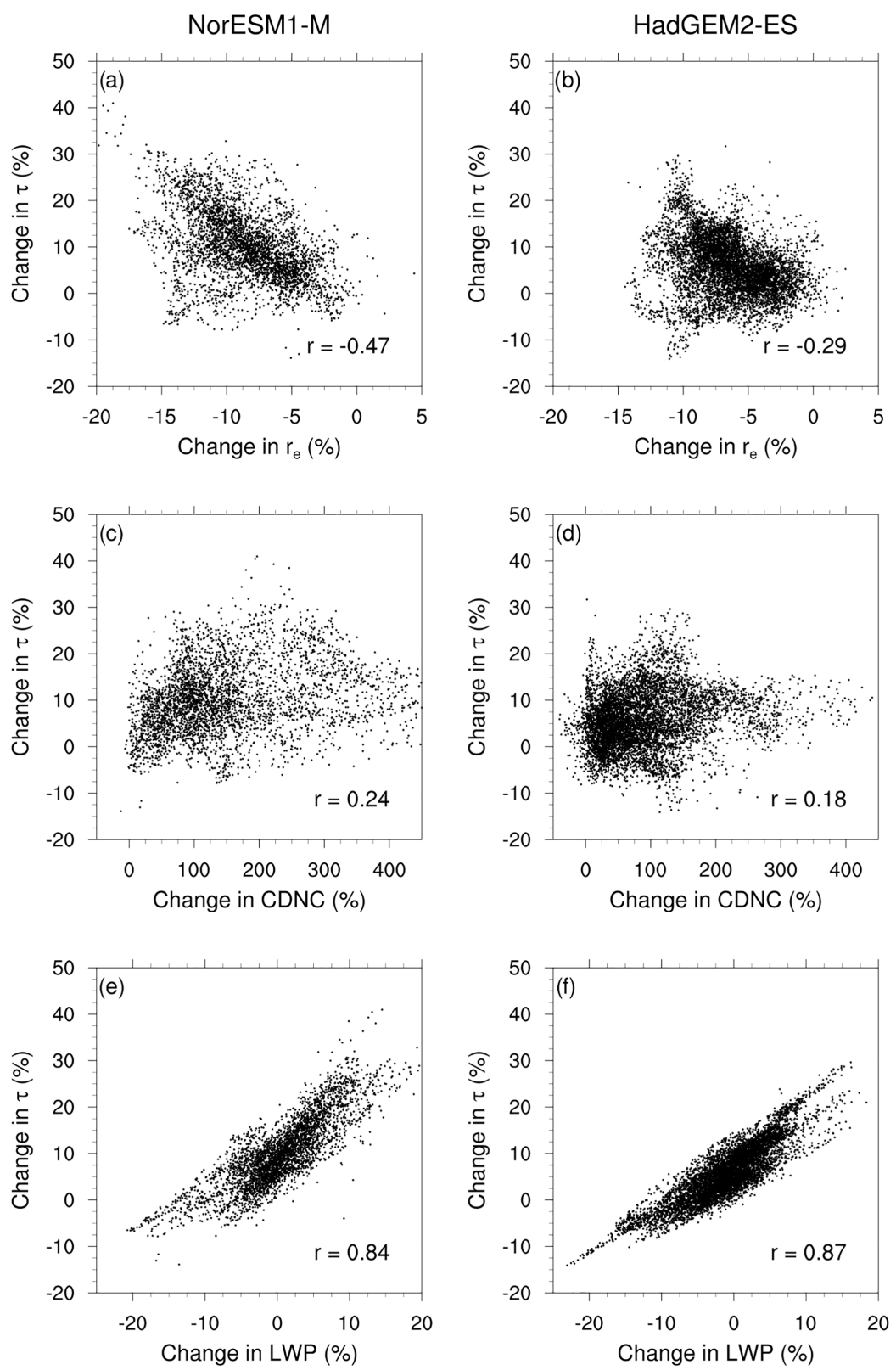

Figure 10. Relations between the relative change in cloud optical depth $(\tau)$ due to sea salt injection against the corresponding changes in $r_{\mathrm{e}}$ for (a) NorESM1-M and (b) HadGEM2-ES; CDNC for (c) NorESM1-M and (d) HadGEM2-ES; and LWP for (e) NorESM1-M and (f) HadGEM2-ES. The relations represent averages over the period 2035-2065 within the injection area. Pearson's correlation coefficient ( $r$ ) is given for each relation.

integrated cloud water content including both liquid water and ice) due to the sea spray climate engineering is more than $15 \%$ locally in all three ESMs (shown as multi-model mean in Fig. 9b), the mean changes globally and over the injection area are less than $2 \%$ in all three models (Table 1). Interestingly, there is no correlation between the change in CDNC and the change in cloud water path within the injection area for mean values of these variables over years 20352065. The Pearson correlation coefficient $r$ for this relation is 0.09 for NorESM1-M, -0.24 for GISS-E2-R, and -0.09 for
HadGEM2-ES. The lack of such a correlation and the fact that the mean change in cloud water path within the injection area is small, and even negative in two of the models (Table 1), indicate that the second aerosol indirect effect is weak (Malavelle et al., 2017). Local changes in cloud water path within the injection area appear instead to be linked to changes in the atmospheric circulation. This is seen in the correlation between the change in cloud water path and the change in omega-vertical velocity (Fig. 9a; $r=-0.70$ for NorESM1-M, $r=-0.59$ for GISS-E2-R, and $r=-0.63$ for 

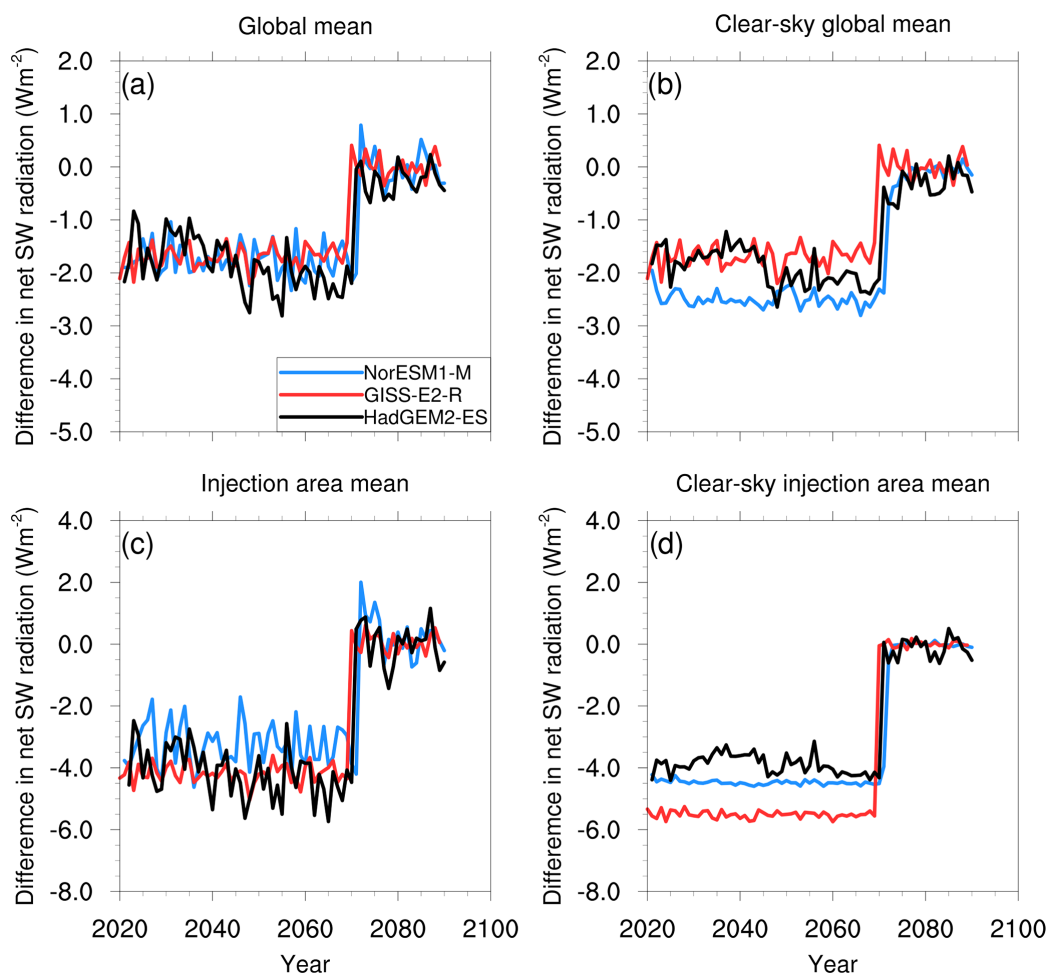

Figure 11. Difference in net SW radiation at the TOA between G4sea-salt and RCP4.5 (a) global mean, (b) clear-sky global mean, (c) injection area mean, and (d) clear-sky injection area mean. The colours denote NorESM1-M (blue), GISS-E2-R (red), and HadGEM2-ES (black). Only grid cells over ocean have been included in the mean values representative of the injection area.

HadGEM2-ES). The negative $r$ coefficients here indicate an increasing cloud water path under increasing upward motion in the atmosphere.

The cloud optical depth $(\tau)$ can be estimated from the cloud liquid water path (LWP) and the cloud droplet effective radius at cloud top $\left(r_{\mathrm{e}}\right)$ through the following relation (Stephens, 1978):

$\tau \approx \frac{3}{2} \frac{L W P}{r_{\mathrm{e}}}$

LWP has units of $\mathrm{g} \mathrm{m}^{-2}$ and $r_{\mathrm{e}}$ is in $\mu \mathrm{m}$. Note that Table 1 gives the change in cloud water path including ice, whereas LWP in Eq. (1) only refers to liquid water. As the estimate of $\tau$ using Eq. (1) requires the variable $r_{\mathrm{e}}, \tau$ could only be estimated for NorESM1-M (Fig. 8b) and HadGEM2-ES (Fig. 8d). As seen in Fig. 8, the sea salt injection results in an increase in $\tau$ in most regions within the injection area in both ESMs. The mean increase in $\tau$ over the injection area is $10 \%$ for NorESM1-M and $6 \%$ for HadGEM2-ES (Table 1). However, locally $\tau$ increases by more than $20 \%$ in both models. An anti-correlation between the relative change in $\tau$ and the corresponding change in $r_{\mathrm{e}}$ exists, although moderate to weak, in the two models (Fig. 10a and b). A negative correlation coefficient is expected due to the Twomey effect. The correlation between the relative changes in $\tau$ and CDNC is even weaker (Fig. 10c and d). By far the strongest correla- tion is the one between the relative changes in $\tau$ and LWP (Fig. 10e and f). Thus, despite the increase in CDNC due to the sea salt injection, it seems that local changes in $\tau$ are controlled largely by changes in LWP, which in turn are caused mainly by changes in the atmospheric circulation.

Figure 9 shows the multi-model mean changes in omegavertical velocity (a), cloud water path (b), and precipitation (c). In large regions over the eastern Pacific Ocean, reduced ascent (or increased subsidence) (Fig. 9a) is accompanied by reductions in cloud water path (Fig. 9b) and precipitation (Fig. 9c). On the other hand, enhanced ascent over, for example, Africa, northern South America, and in the South Pacific Convergence Zone coincides with increased cloud water path and precipitation. These patterns of enhanced cloud water, precipitation, and atmospheric upward motion over low-latitude continents combined with reduced cloud water, precipitation, and ascent over some lowlatitude ocean regions have been reported previously by Bala et al. (2011), Alterskjær et al. (2013), Niemeier et al. (2013), Crook et al. (2015), and Stjern et al. (2017). This is a result of reduced absorption of solar radiation over ocean where sea salt concentrations are elevated while continental regions are left less affected, increasing the land-sea gradient over the tropics. This induces enhanced convection over land and thereby increased cloud formation and precipitation and reduced cloud formation over ocean due to reduced upward 

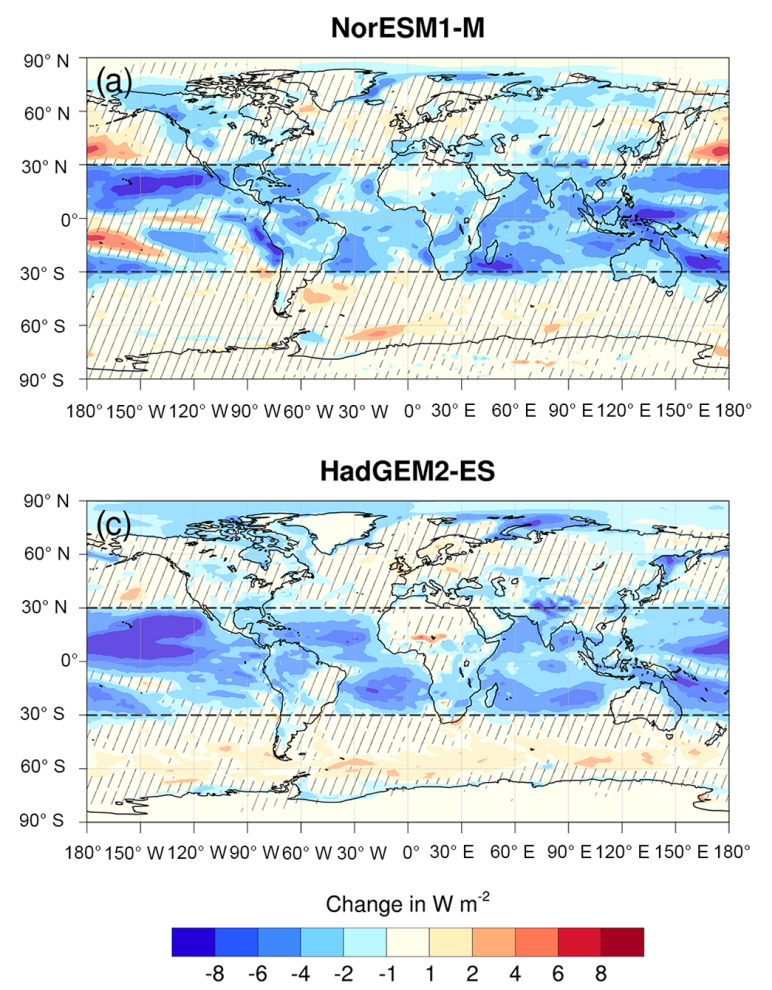

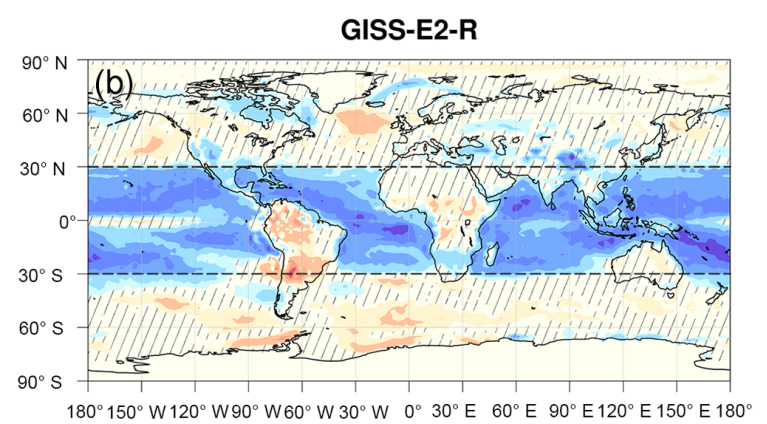

Figure 12. Mean change in net SW radiation $\left(\mathrm{Wm}^{-2}\right)$ at the TOA between G4sea-salt and RCP4.5 for the period $2035-2065$ for (a) NorESM1-M, (b) GISS-E2-R, and (c) HadGEM2-ES. Hatching denotes areas where changes are not significant at the $95 \%$ confidence level (Student $t$ test with respect to variance of annual mean values).

motion or increased subsidence. Furthermore, the increase in upward motion and cloud water content north-east of Australia, and the reduction in these variables over the eastern Pacific Ocean west of South America, indicate a strengthening of the Pacific Walker cell and South Pacific Convergence Zone.

In summary, the aerosol indirect effect of the injected sea salt particles can be seen in the mean increase in CDNC, mean decrease in cloud-top effective droplet radius, and mean increase in cloud optical depth over the injection area. However, in these fully coupled simulations the aerosol direct and indirect effects of the injected sea salt particles also cause changes in the atmospheric circulation that generate a redistribution of cloud water, with increasing cloud water and precipitation in regions of enhanced atmospheric ascent and decreasing cloud water and precipitation in regions of decreased atmospheric upward motion. Within the injection area, the local response in cloud optical depth is controlled to a larger extent by these changes in cloud water than by changes in CDNC or $r_{\mathrm{e}}$. This means that it is not necessarily the regions that are exposed to the largest aerosol indirect effect of the injected particles that are exposed to the largest enhancement in cloud albedo.

\subsubsection{Change in net SW radiation at the TOA}

The global-mean difference in net SW radiation at the TOA (Fig. 11a) between G4sea-salt and RCP4.5 is rather constant at $-2.0 \mathrm{~W} \mathrm{~m}^{-2}$ throughout the 50 years of sea spray climate engineering in NorESM1-M and GISS-E2-R, and hence similar in magnitude to the global-mean ERF by the sea salt injection. Thus, in these two ESMs a constant sea salt injection in time increases the planetary albedo by a factor that is roughly constant in time, despite slow feedbacks being included in these fully coupled simulations. In HadGEM2ES, the difference in net SW radiation at the TOA between G4sea-salt and RCP4.5 is increasing somewhat during the 50 years of sea spray climate engineering, which means that a constant sea salt injection rate in HadGEM2-ES generates a slowly increasing planetary albedo. Positive cloud feedback should be contributing to this in HadGEM2-ES, which will act to increase the radiative effect of climate engineering over time, in contrast to the negative cloud feedback in NorESM1M (Andrews et al., 2012). However, there is also some indication of an increasing difference in net SW radiation between G4sea-salt and RCP4.5 over time in HadGEM2-ES for the clear-sky fluxes (Fig. 11b), indicating a contribution from the sea ice albedo feedback. The reduction in net SW radiation at the TOA over the Arctic region, caused by the sea spray climate engineering, is larger in HadGEM2- 
ES (Fig. 12c) than in the two other ESMs (Fig. 12a and b), which indicates that the sea ice albedo feedback is strongest in HadGEM2-ES. HadGEM2-ES also has a larger reduction in surface temperature than the other two models for the Arctic region (not shown). However, reductions in global-mean surface temperature are very similar in the three models (Table 1).

Whereas the global-mean changes in net SW radiation at the TOA shown in Fig. 11a and b are to some extent influenced by changes in surface albedo, the corresponding changes over the injection area over ocean between $30^{\circ} \mathrm{N}$ and $30^{\circ} \mathrm{S}$ are only due to atmospheric changes (Fig. 11c and d). As expected, the reductions in net SW radiation are on average larger between $30^{\circ} \mathrm{N}$ and $30^{\circ} \mathrm{S}$, where the sea salt injection occurs, than globally. The total change in net SW radiation over the injection area (Fig. 11c) is rather constant with time in NorESM1-M and GISS-E2-R, similar to the global-mean curves in Fig. 11a, but slowly increasing with time in HadGEM2-ES. The change in clear-sky net SW radiation over the injection area (Fig. 11d) is rather constant with time in all three ESMs. Similar to the ERF in Fig. 3, the change in clear-sky net SW radiation over the injection area is almost equal to the total change in net SW radiation in the three ESMs, again indicating a large potential of the aerosol direct effect in regions of low cloudiness. In GISS-E2-R and NorESM1-M, the change in net SW radiation is even larger in clear-sky conditions than in total.

\section{Conclusions}

In this study, we have analysed the GeoMIP G4sea-salt experiment using three different ESMs: NorESM1-M, GISSE2-R, and HadGEM2-ES. Sea spray climate engineering is applied on top of the RCP4.5 scenario between years 2020 and 2070, with sea salt injection rates set to generate a globalmean ERF of $-2.0 \mathrm{~W} \mathrm{~m}^{-2}$.

Although sea spray climate engineering is often referred to as marine cloud brightening, we find that the global-mean clear-sky ERF is as large as the total ERF in all three ESMs, indicating the large potential of the aerosol direct effect in regions of low cloudiness. The largest regional enhancement in ERF due to the presence of clouds, compared to the ERF in clear-sky conditions, occurs as expected in the subtropical stratocumulus regions off the west coasts of the American and African continents. However, in most regions outside these subtropical regions, the clear-sky ERF is as large as the total ERF. Furthermore, the correlation between lowlevel cloud cover and the strength of the ERF by the injected particles within the injection area is weak or non-existent in the models. These factors together indicate that, with the exception of the subtropical stratocumulus regions, sea spray climate engineering is as efficient in clear-sky conditions as in cloudy-sky conditions.
The aerosol indirect effect of the injected particles is seen in the increase in CDNC, reduction in $r_{\mathrm{e}}$, and increase in cloud optical depth over the injection area. However, sea spray climate engineering also causes changes in the atmospheric circulation, which results in a redistribution of cloud water. We find that the local response of the cloud optical depth depends to a larger extent on changes in the LWP than on changes in CDNC or in $r_{\mathrm{e}}$.

These results show that many important secondary effects on clouds are neglected if sea spray climate engineering is investigated by the simplified method of increasing the number of cloud droplets, as has been done previously in a number of studies (Latham et al., 2008; Jones at al., 2009; Rasch et al., 2009), or when considering injection in a limited area (Jones and Haywood, 2012). The results here may also have implications for which regions may be most effective in generating a cooling from sea spray injection, as the aerosol direct effect likely plays a more important role than previously thought.

Data availability. All model data are available through the Earth System Grid or upon request to the contact author.

Competing interests. The authors declare that they have no conflict of interest.

Special issue statement. This article is part of the special issue "The Geoengineering Model Intercomparison Project (GeoMIP): Simulations of solar radiation reduction methods (ACP/GMD interjournal SI)". It is not associated with a conference.

Acknowledgements. Lars Ahlm, Helene Muri, Camilla W. Stjern, and Jón Egill Kristjánsson were supported by the Research Council of Norway (grant number 229760/E10) (EXPECT). Lars Ahlm was also supported by the NordForsk approved Nordic Centre of Excellence "CRAICC", and by the Swedish Research Council FORMAS (grant 2015-748). Helene Muri received further funding from RCN grant 261862/E10. Norwegian Research Council's Program for supercomputing, NOTUR, provided computing time (NN9182K). Data storage on Norstore (NS9033K, NS2345K). Simulations with GISS-E2-R, performed by Ben Kravitz, were supported by the NASA High-End Computing (HEC) Program through the NASA Center for Climate Simulation (NCCS) at Goddard Space Flight Center. The Pacific Northwest National Laboratory is operated for the US Department of Energy by Battelle Memorial Institute under contract DE-AC05-76RL01830. We also thank all participants of the Geoengineering Model Intercomparison Project and their model development teams, CLIVAR/WCRP Working Group on Coupled Modeling for endorsing GeoMIP, and the scientists managing the Earth System Grid data nodes who have assisted with making GeoMIP and CMIP5 output available.

Edited by: Ulrike Lohmann

Reviewed by: two anonymous referees 


\section{References}

Albrecht, B. A.: Aerosols, cloud microphysics, and fractional cloudiness, Science, 245, 1227-1230, 1989.

Alterskjær, K. and Kristjánsson, J. E.: The sign of the radiative forcing from marine cloud brightening depends on both particle size and injection amount, Geophys. Res. Lett., 40, 210-215, https://doi.org/10.1029/2012GL054286, 2013.

Alterskjær, K., Kristjánsson, J. E., and Seland, Ø.: Sensitivity to deliberate sea salt seeding of marine clouds - observations and model simulations, Atmos. Chem. Phys., 12, 2795-2807, https://doi.org/10.5194/acp-12-2795-2012, 2012.

Alterskjær, K., Kristjánsson, J. E., Boucher, O., Muri, H., Niemeier, U., Schmidt, H., Schulz, M., and Timmreck, C.: Sea-salt injections into the low-latitude marine boundary layer: the transient response in three Earth system models, J. Geophys. Res.-Atmos., 118, 12195-12206, https://doi.org/10.1002/2013JD020432, 2013.

Andrews, T., Gregory, J. M., Webb, M. J., and Taylor, K. E.: Forcing, feedbacks, and climate sensitivity in CMIP5 coupled atmosphere-ocean climate models, Geophys. Res. Lett., 39, L09712, https://doi.org/10.1029/2012GL051607, 2012.

Bala, G., Caldeira, K., Nemani, R., Cao, L., Ban-Weiss, G., and Shin, H.-J.: Albedo enhancement of marine clouds to counteract global warming: impacts on the hydrological cycle, Clim. Dynam., 37, 915-931, https://doi.org/10.1007/s00382-010-0868-1, 2011.

Bellouin, N., Rae, J., Jones, A., Johnson, C., Haywood, J., and Boucher, O.: Aerosol forcing in the Climate Intercomparison Project (CMIP5) simulations by HadGEM2-ES and the role of ammonium nitrate, J. Geophys. Res.-Atmos., 116, D20206, https://doi.org/10.1029/2011JD016074, 2011.

Bentsen, M., Bethke, I., Debernard, J. B., Iversen, T., Kirkevåg, A., Seland, Ø., Drange, H., Roelandt, C., Seierstad, I. A., Hoose, C., and Kristjánsson, J. E.: The Norwegian Earth System Model, NorESM1-M - Part 1: Description and basic evaluation of the physical climate, Geosci. Model Dev., 6, 687-720, https://doi.org/10.5194/gmd-6-687-2013, 2013.

Collins, W. J., Bellouin, N., Doutriaux-Boucher, M., Gedney, N., Halloran, P., Hinton, T., Hughes, J., Jones, C. D., Joshi, M., Liddicoat, S., Martin, G., O'Connor, F., Rae, J., Senior, C., Sitch, S., Totterdell, I., Wiltshire, A., and Woodward, S.: Development and evaluation of an Earth-System model - HadGEM2, Geosci. Model Dev., 4, 1051-1075, https://doi.org/10.5194/gmd-4-10512011, 2011.

Connolly, P. J., McFiggans, G. B., Wood, R., and Tsiamis, A.: Factors determining the most efficient spray distribution for marine cloud brightening, Philos. T. R. Soc. A, 372, 20140056, https://doi.org/10.1098/rsta.2014.0056, 2014.

Crook, J. A., Jackson, L. S., Osprey, S. M., and Forster, P. M.: A comparison of temperature and precipitation responses to different Earth radiation management geoengineering schemes, J. Geophys. Res.-Atmos., 120, 9352-9373, https://doi.org/10.1002/2015JD023269, 2015.

de Leeuw, G., Andreas, E. L., Anguelova, M. D., Fairall, C. W., Lewis, E. R., O'Dowd, C. D., Schulz, M., and Schwartz, S. E.: Production flux of sea-spray aerosol, Rev. Geophys., 49, RG2001, https://doi.org/10.1029/2010RG000349, 2011.

Fitzgerald, J. W.: Approximation formulas for the equilibrium size of an aerosol particle as a function of its dry size and composition and the ambient relative humidity, J. Appl. Meteorol., 14, 10441049, 1975.

Iversen, T. and Seland, $\varnothing .:$ A scheme for process-tagged SO4 and BC aerosols in NCAR CCM3: Validation and sensitivity to cloud processes, J. Geophys. Res.-Atmos., 107, 4751, https://doi.org/10.1029/2001JD000885, 2002.

Jones, A. and Haywood, J. M.: Sea-spray geoengineering in the HadGEM2-ES earth-system model: radiative impact and climate response, Atmos. Chem. Phys., 12, 10887-10898, https://doi.org/10.5194/acp-12-10887-2012, 2012.

Jones, A., Roberts, D. L., Woodage, M. J., and Johnson, C. E.: Indirect sulphate aerosol forcing in a climate model with an interactive Sulphur cycle, J. Geophys. Res.-Atmos., 106, 20293-20310, https://doi.org/10.1029/2000JD000089, 2001.

Jones, A., Haywood, J., and Boucher, O.: Climate impacts of geoengineering marine stratocumulus clouds. J. Geophys. Res.Atmos., 114, D10106, https://doi.org/10.1029/2008JD011450, 2009.

Kirkevåg, A. and Iversen, T.: Global direct radiative forcing by process-parameterized aerosol optical properties, J. Geophys. Res.-Atmos., 107, 4433, https://doi.org/10.1029/2001JD000886, 2002.

Koch, D., Bond, T. C., Streets, D., Unger, N., van der Werf, G. R.: Global impacts of aerosols from particular source regions and sectors, J. Geophys. Res.-Atmos., 112, D02205, https://doi.org/10.1029/2005JD007024, 2007.

Korhonen, H., Carslaw, K. S., and Romakkaniemi, S.: Enhancement of marine cloud albedo via controlled sea spray injections: a global model study of the influence of emission rates, microphysics and transport, Atmos. Chem. Phys., 10, 4133-4143, https://doi.org/10.5194/acp-10-4133-2010, 2010.

Kravitz, B., Robock, A., Boucher, O., Schmidt, H., Taylor, K. E., Stenchikov, G., and Schulz, M.: The Geoengineering Model Intercomparison Project (GeoMIP), Atmos. Sci. Lett., 12, 162167, https://doi.org/10.1002/asl.316, 2011.

Kravitz, B., Forster, P. M., Jones, A., Robock, A., Alterskjær, K., Boucher, O., Jenkins, A. K. L., Korhonen, H., Kristjánsson, J. E., Muri, H., Niemeier, U., Partanen, A.-I., Rasch, P. J., Wang, H., and Watanabe, S.: Sea spray geoengineering experiments in the geoengineering model intercomparison project (GeoMIP): experimental design and preliminary results, J. Geophys. Res.Atmos., 118, 11175-11186, https://doi.org/10.1002/jgrd.50856, 2013.

Latham, J.: Control of global warming? Nature, 347, 339-340, 1990.

Latham, J., Rasch, P., Chen, C.-C., Kettles, L., Gadian, A., Gettelman, A., Morrison, H., Bower, K., and Choularton, T.: Global temperature stabilization via controlled albedo enhancement of low-level maritime clouds, Philos. T. R. Soc. A, 366, 3969-3987, https://doi.org/10.1098/rsta.2008.0137, 2008.

Malavelle, F. F., Haywood, J. M., Jones, A., Gettelman, A., Clarisse, L., Bauduin, S., Allan, R. P., Karset, I. H. H., Kristjánsson, J. E., Oreopoulos, L., Cho, N., Lee, D., Bellouin, N., Boucher, O., Grosvenor, D. P., Carslaw, K. S., Dhomse, S., Mann, G. W., Schmidt, A., Coe, H., Hartley, M. E., Dalvi, M., Hill, A. A., Johnson, B. T., Johnson, C. E., Knight, J. R., O’Connor, F. M., Partridge, D. G., Stier, P., Myhre, G., Platnick, S., Stephens, G. L., Takahashi, H., and Thordarson, T.: Strong constraints on aerosol- 
cloud interactions from volcanic eruptions, Nature, 546, 485491, https://doi.org/10.1038/nature22974, 2017.

Meinshausen, M., Schmidt, S. J., Calvin, K., Daniel, J. S., Kainuma, M. L. T., Lamarque, J.-F., Matsumoto, K., Montzka, S. A., Raper, S. C. B., Riahi, K., Thomson, A., Velders, G. J. M., and van Vuuren, D. P. P.: The RCP greenhouse gas concentrations and their extensions from 1765 to 2300, Clim. Change, 109, 213, https://doi.org/10.1007/s10584-011-0156-z, 2011.

Monahan, E. C., Spiel, D. E., and Davidson, K. L.: A model of marine aerosol generation via whitecaps and wave disruption, in: Oceanic Whitecaps, edited by: Monahan, E. C. and Mac Niocaill, G., Springer, New York, 167-174, 1986.

Muri, H., Niemeier, U., and Kristjánsson, J. E.: Tropical rainforest response to marine sky brightening, Geophys. Res. Lett., 42, 2951-2960, https://doi.org/10.1002/2015GL063363, 2015.

Niemeier, U., Schmidt, H., Alterskjær, K., and Kristjánsson, J. E.: Solar irradiance reduction via climate engineering: impact of different techniques on the energy balance and the hydrological cycle, J. Geophys. Res.-Atmos., 118, 11905-11917, https://doi.org/10.1002/2013JD020445, 2013.

Partanen, A.-I., Kokkola, H., Romakkaniemi, S., Kerminen, V.-M., Lehtinen, K. E. J., Bergman, T., Arola, A., and Korhonen, H.: Direct and indirect effects of sea-spray geoengineering and the role of injected particle size, J. Geophys. Res.-Atmos., 117, D02203, https://doi.org/10.1029/2011JD016428, 2012.

Rasch, P. J., Latham, J., and Chen, C.-G.: Geoengineering by cloud seeding: influence on sea ice and climate system, Environ. Res. Lett., 4, 045112, https://doi.org/10.1088/1748-9326/4/4/045112, 2009.

Rossow, W. B. and Schiffer, R. A.: Advances in understanding clouds from ISCCP, B. Am. Meteorol. Soc., 80, 2261-2288, 1999.

Salter, S., Sortino, G., and Latham, J.: Sea-going hardware for the cloud albedo method of reversing global warming, Philos. T. Roy. Soc. A, 366, 3989-4006, https://doi.org/10.1098/rsta.2008.0136, 2008.

Schmidt, G. A., Ruedy, R., Hansen, J. E., Aleinov, I., Bell, N., Bauer, M., Bauer, S., Cairns, B., Canuto, V., Ye, C., del Genio, A., Faluvegi, G., Friend, A. D., Hall, T. M., Yongyun, H., Kelley, M., Kiang, N. Y., Koch, D., Lacis, A. A., and Lerner, J.: Present day atmospheric simulations using GISS modelE: comparison to in-situ, satellite and reanalysis data, J. Climate, 19, 153-192, 2006.

Schmidt, G. A., Kelley, M., Nazarenko, L., Ruedy, R., Russell, G. L., Aleinov, I., Bauer, M., Bauer, S. E., Bhat, M. K., Bleck, R., Canuto, V., Chen, Y.-H., Cheng, Y., Clune, T. L., Del Genio, A., de Fainchtain, R., Faluvegi, G., Hansen, J. E., Healy, R. J., Kiang, N. Y., Koch, D., Lacis, A. A., LeGrande, A. N., Lerner, J., Lo, K. K., Matthews, E. E., Menon, S., Miller, R. L., Oinas, V., Oloso, A. O., Perlwitz, J. P., Puma, M. J., Putman, W. M., Rind, D., Romanou, A., Sato, M., Shindell, D. T., Sun, S., Syed, R. A., Tausnev, N., Tsigaridis, K., Unger, N., Voulgarakis, A., Yao, M.-S., and Zhang, J.: Configuration and assessment of the GISS ModelE2 contributions to the CMIP5 archive, J. Adv. Model. Earth Sy., 6, 141-184, https://doi.org/10.1175/JCLI3612.1, 2014.
Seinfeld, J. H. and Pandis, S. N.: Atmospheric Chemistry and Physics: From Air Pollution to Climate Change, John Wiley \& Sons, Inc., Canada, 1998.

Seland, Ø., Iversen, T., Kirkevåg, A., and Storelvmo, T.: Aerosolclimate interactions in the CAM-Oslo atmospheric GCM and investigation of associated basic shortcomings, Tellus A, 60, 459491, 2008.

Stephens, G. L.: Radiation profiles in extended water clouds. II: Parameterization schemes, J. Atmos. Sci., 35, 2123-2132, 1978.

Stjern, C. W., Muri, H., Ahlm, L., Boucher, O., Cole, J. N. S., Ji, D., Jones, A., Haywood, J., Kravitz, B., Lenton, A., Moore, J. C., Niemeier, U., Phipps, S. J., Schmidt, H., Watanabe, S., and Kristjánsson, J. E.: Response to marine cloud brightening in a multi-model ensemble, Atmos. Chem. Phys. Discuss., https://doi.org/10.5194/acp-2017-629, in review, 2017.

Struthers, H., Ekman, A. M. L., Glantz, P., Iversen, T., Kirkevåg, A., Mårtensson, E. M., Seland, Ø., and Nilsson, E. D.: The effect of sea ice loss on sea salt aerosol concentrations and the radiative balance in the Arctic, Atmos. Chem. Phys., 11, 3459-3477, https://doi.org/10.5194/acp-11-3459-2011, 2011.

Taylor, K. E., Stouffer, R. J., and Meehl, G. A.: An overview of CMIP5 and the experiment design, B. Am. Meteorol. Soc., 93, 485-498, https://doi.org/10.1175/BAMS-D-11-00094.1, 2011.

Titos, G., Cazorla, A., Zieger, P., Andrews, E., Lyamani, H., Granados-Muñoz, M. J., Olmo, F. J., and Alados-Arboledas, L. Effect of hygroscopic growth on the aerosol light-scattering coefficient: a review of measurements, techniques and error sources, Atmos. Environ., 141, 494-507, 2016.

Twomey, S.: The influence of pollution on the shortwave albedo of clouds, J. Atmos. Sci., 34, 1149-1152, 1977.

Wang, H., Rasch, P. J., and Feingold, G.: Manipulating marine stratocumulus cloud amount and albedo: a process-modelling study of aerosol-cloud-precipitation interactions in response to injection of cloud condensation nuclei, Atmos. Chem. Phys., 11, 4237-4249, https://doi.org/10.5194/acp-11-4237-2011, 2011.

Wood, R.: Stratocumulus clouds, Mon. Weather Rev., 140, 2373 2423, 2012.

Zieger, P., Fierz-Schmidhauser, R., Weingartner, E., and Baltensperger, U.: Effects of relative humidity on aerosol light scattering: results from different European sites, Atmos. Chem. Phys., 13, 10609-10631, https://doi.org/10.5194/acp-13-106092013, 2013. 